\title{
University of Texas Bulletin
}

No. 2065: November 20, 1920

The Seed Plants, Ferns, and Fern Allies of the Austin Region

\author{
By \\ Mary Sophie Young, Ph.D.
}

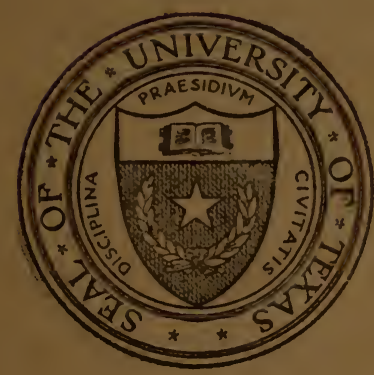




\title{
Publications of the University of Texas
}

\author{
Publications Committee:
}

FREDERIC DUNCALF

C. T. GRAY

KILLIS CAMPBELL

E. J. MATHEWS

D. B. CASTEEL

C. E. Rowe

F. W. GRAFF

A. E. TROMBLY

The University publishes bulletins six times a month, so numbered that the first two digits of the number show the year of issue, the last two the position in the yearly series. (For example, No. 1701 is the first bulletin of the year 1917.) These comprise the official publications of the University, publications on humanistic and scientific subjects, bulletins prepared by the Bureau of Extension, by the Bureau of Government Research, and by the Bureau of Economic Geology and Technology, and other bulletins of general educational interest. With the exception of special numbers, any bulletin will be sent to a citizen of Texas free on request. All communications about University publications should be addressed to University Publications, University of Texas, Austin. 


\title{
University of Texas Bulletin
}

No. 2065: November 20, 1920

\section{The Seed Plants, Ferns, and Fern Allies of the Austin Region}

\author{
By
}

Mary Sophie Young, Ph.D.

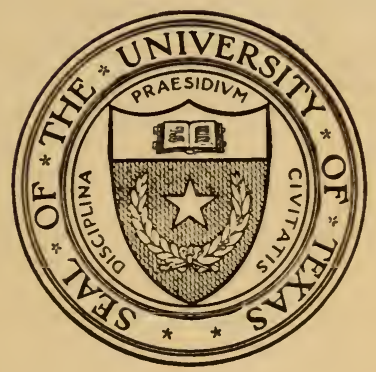

PUBLISHED BY THE UNIVERSITY SIX TIMES A MONTH, AND ENTERED AS? SECOND-CLASS MATTER AT THE POSTOFFICE AT AUSTIN, TEXAS.

UNDBR THE ACT OF AUGUST 24, 1912 
The benefits of education and of useful knowledge, generally diffused through a community, are essential to the preservation of a free govern. ment.

Sam Houston

Cultivated mind is the guardian genius of democracy. ... It is the only dictator that freemen acknowledge and the only security that freemen desire.

Mirabeau B. Lamar 


\section{PREFACE}

The manuscript for this publication was prepared by Dr. Mary Sophie Young from material of twa sources: her own collections and those placed in the hərbarium by various other botanists who preceded her at the University of Texas. It embodies, with very few exceptions, only those species whose identity she considered un questionable, leaving out numerous other species which she considered doubtfully placed or perhaps undescribed. While a majority of the species to be found in the vicinity of Austin are certainly included, this work is not to be expected to include them all. It represents six years of as intensive collection as was possible for an enthusiastic, enegetic, and thoroughly capable person who was doing at the same time a full share of teaching work. Very few, if any, specimens found in the herbarium when she began were not verified or corrected by her own collections. But to obtain what would justly be termed a complete representation of practically all the species to be found in the Austin region will require many years of intensive collection on the part of a corps of workers whose full time shall be devoted to this work alone. Nevertheless, this bulletin does constitute an invaluable foundation upon which subsequent workers may build with comparative ease. With exceptional skill Dr. Young has in it not only blazed a trail; she has actually builded a highway.

The manuscript was complete except the preface at the time of her death, March 5, 1919. It is here offered without amendments other than the insertion of a few descriptions where she had indicated her purpose to put them. Planned to supplement her Key to the Families and Genera of the Wild Plants of Austin, Texas, it should be used in conjunction with that work. The two together should bring the identification of the commoner plants of central Texas within the power of any person who is reasonably intelligent and who is willin? to devote a little time to familiarizing himself with a few technical terms which are essential to brevity and clearness in description.

With certainty that it constitutes a valuable contribution to the science of systematic botany, and with confidence that it will fill a need expressed by frequent letters of request for reference to "some work that will enable one to know the wild flowers of Texas," thus stimulating interest in a study of systematic botany on the part of lay students over the state, this posthumous publication is offered the Texas public.

\section{B. C. THARP.}

Nov. 8, 1920.

Department of Botany, University of Texas. 



\title{
THE SEED PLANTS, FERNS AND FERN ALLIES OF THE AUSTIN REGION
}

\author{
PTERIDOPHYTES \\ OPHIOGLOSSALES
}

OPHIOGLOSSACEAE Adder's-tongue Family

Ophioglossum Engelmanni Prantle. Adder's Tongue.

Rich soil in woods near dam.

Southeastern states.

\section{FILICALES}

\section{SCHIZAEACEAE Curley-grass Family}

Anemia mexicana KL. (Ornithopteris mexicana Underw.).

Rich soil in moist shaded slopes in "Devil's Hollow" a tributary canyon of the Colorado about 10 miles above Austin. A large fern with glossy leathery leaves of which the lowest pair of pinnae are elongated and spore-bearing.

Texas and Mexico.

\section{POLYPODIACEAE}

Adiantum Capillus-veneris L. Maidenhair fern.

Our most common fern. Very abundant on moist rock bluffs, over-hanging the river and in ravines.

Warm temperate regions.

Asplenium resiliens Kuntze. Spleen wort.

On rock bluffs in ravines. A small fern with slender pinnate leaves.

Southeastern states, Mexico and Jamaica.

Cheilanthes alabamensis Kuntze. Lip-fern.

On rock bluffs in ravines. The leaves are twice pinnate and some of the segments lobed.

Southeastern states to Mexico.

Dryopteris patens Kuntze. Shield-fern.

A large, showy fern, with leaves erect or ascending, three or four feet long.

Bull Creek region.

Southeastern states, California and Tropical America. 
Notholaena dealbata Kuntze.

On rock bluffs along Barton Creek and Onion Creek. A small fern with its leaflets whitened below.

Southern central states.

Pellaea atropurpurea Link. Cliff-brake.

Rock bluffs in ravines. The leaves are twice pinnate below, once above. The leathery leaflets are spore-bearing around their margins. The rachis is black.

Widespread in North America.

Pellaea flexuosa Link.

Moist ravines. Larger than the preceding with leaves thrice pinnate. Easily recognized by its pink zigzag rachis divisions. A very beautiful and singular fern.

California to Texas and Mexico and in South America.

Polypodium polypodioides A. S. Hitchcock (P. incanum Sw.). Polypody.

A small fern growing on tree trunks. The leathery evergreen leaves are covered on the under surface with reddish-centered gray scales.

Southeastern states and tropical America.

\section{SALVINIALES}

\section{MARSILEACEAE Mafsilea Family}

Marsilea vestita Hook \& Grev. Water Fern.

Abundant in muddy ground along creeks. A slender stemmed creeping perennial with leaves similar to a 4-leafed clover.

Widespread in North America.

\section{EQUISETALES}

\section{EQUISETACEAE Horsetail Family}

Equisetum robustum A. Br. Horsetail, Scouring Rush.

Along the bank of Barton Creek above the bridge, and on Walnut Creek.

A leafless rush-like plant with hollow, pointed stems.

Widespread in North America. 


\section{LYCOPODIALES}

\section{SELAGINELLACEAE Selaginella Family}

Selaginella apus Spring. Creeping Selaginella.

Wet ground along Onion Creek. A delicate creeping, moss-like plant.

Widespread in eastern North America.

Selaginella arenicola Underw.

Abundant in the post oak woods. It has the appearance of a coarse moss with the stem tip upright and tufted.

Southeastern states.

\section{GYMNOSPERMS}

PINALES (CONIFERALES)

\section{JUNIPERACEAE Juniper Family}

Taxodium distichum L. C. Rich. Cypress, Swamp Cypress, Bald Cypress.

Along the Colorado River, and on Onion Creek.

A large and beautiful deciduous conifer tree, abundant in the cypress swamps of east Texas. Occurring in similar habitats in the Atlantic and Gulf coastal regions and in the southern Mississippi Valley.

Sabina sabinoides Small. (Juniperus sabinoides Sargent) Mountain Cedar.

Abundant on limestone hillsides, especially of the Edwards Plateau, often forming pure cedar forests.

A Texas and New Mexican species, probably derived from S. virginiana.

Sabina virginiana Antoine. (Juniperus virginiana L.). Red Cedar.

Occasional in the valleys, and in the more moist woods with $S$. sabinoides. The berries are smaller than those of the preceding species and the twigs more slender.

The common red cedar of the eastern states.

\section{GNETALES}

\section{GNETACEAE Gnetum Family}

Ephedra nevadensis Wats. Joint Fir.

A leafless shrub with slender, jointed, green branches, found in a fory p'acss on the bluffs of the Colorado River and Barton Creek.

$\Lambda$ characteristic plant of the arid southwest. 


\section{ANGIOSPERMS}

\section{MONOCOTYLEDONS}

\section{PANDANALES}

\section{TYPHACEAE Cat-tail Family}

Typha latifolia L. Cat-tail.

In the ponds of the Insane Asylum and of the University campus.

One of the most wide-spread of plants. In ponds throughout almost the entire northern hemisphere.

\section{NAIADALES}

\section{ZANICHELliACEAE, Pondweed Family (Under Naiadacease)}

Zanichellia palustris L. Horned Pondweed.

Abundant in Barton Creek and the Asylum ponds, growing submerged. A delicate, slender plant with narrow leaves.

Widespread in the northern hemisphere.

Potamogeton lucens L. Pondweed.

Abundant in Barton Creek and in the ponds of the Asylum. Submerged, except the flower stalks and flower clusters.

Widespread in North America and Europe.

\section{ALISMALES}

\section{ALISMACEAE Water-plantain Family}

Sagittaria platyphylla J. G. Smith. Arrow-leaf, Arrow-head.

Abundant in Barton Creek. Partly submerged. Its leaf blades and clusters of white flowers exserted from the water.

Ponds and swamps of the southern Mississippi Valley and Texas.

\section{POALES (GRAMINALES)}

\section{POACEAE (GRAMINEAE) Grass Family}

Tribe Ardropogoneae

Amphilophis saccharoides (Sw.) Nash. Beard Grass. Abundant in dry ground.

Andropogon argyraeus Schult. Silver Beard Grass.

Abundant in dry open grounds.

Southeastern states. 
Andropogon glomeratus B. S. P.

Near the mouth of Barton Creek, along the stream.

Southern states.

Schizachyrium scoparium Nash. (Andropogon scoparius Michx. Broom Grass. Blue-stem.

In dry open ground, along railroad tracks and roadsides.

Widely distributed throughout the eastern and central states.

Sorghastrum nutans Nash. Indian Grass.

Waste ground along railroad tracks. A coarse grass, four or five feet tall.

Widespread in the eastern United States.

Sorghum halepense Pers. Johnson Grass.

Abundant everywhere in fields and waste places.

Introduced from Europe and Asia. Widely distributed in the southern and eastern states.

\section{Tribe Zoysieae}

Hilaria texana Nash. (H. cenchroides var. texana Vasey.) Creeping Mesquite.

Abundant on dry hillsides and in open ground along railroad tracks, etc.

From central Texas to Arizona and Mexico.

Nazia aliena Scribn. Prickle-grass, Burdock-grass.

Occasional in waste places. Along railroad tracks.

Introduced from Europe and Asia. Abundant in the Rio Grande Valley and near the Gulf Coast.

\section{Tribe Tristegineae}

Limnodea arkansana pilosa Nash.

Abundant in dry ground.

Louisiana and Texas.

Tribe Paniceae

Cenchrus tribuloides L. Grass Bur. Bur-grass. Sand Bur. $(C$. carolinianus Walt. not $C$. tribuloides Britton and Brown.)

Dry open ground. University campus, etc. Abundant and very troublesome in lawns.

Widespread throughout the eastern and central states. 
Chaetochloa composita Scribn. Foxtail Grass.

Common in low ground.

South-central states and tropical America.

Chaetochloa glauca Scribn. Pigeon Grass. Yellow Foxtail. (Setaria glauca L.)

Waste places. University campus.

Widespread in North America. Native of Europe.

Chaetochloa verticillata Scribn. (Setaria verticillata Beauv.) Foxtail Grass.

Roadsides and waste places.

Introduced from Europe. Widespread in the United States.

Echinochloa colona Link. (Panicum colonum L.) Jungle Rice.

Low ground and cultivated fields.

Southeastern states.

Panicum cognatum Schult. (P. autumnale Bose.) Fa!l Witch Grasふ.

Dry and waste ground.

Widespread in the eastern and central states.

Panicum fuscum Sw.

University campus.

Southern Florida and Texas.

Panicum Helleri Nash.

Dry, rocky hillsides.

Southern Texas.

Panicum Lindheimeri Nash.

Rather rare.

Southeastern states.

Panicum obtusum HBK. Wire Grass.

Cultivated ground, University campus.

Southern plains states.

Panicum Reverchonii Vasey. "Chaparral Millett."

Roadsides, etc.

Texas.

Panicum Scribnerianum Nash.

Dry hillsides. Roadsides.

Widespread in eastern and central states. 
Panicum texanum Buckl. Texas Millet.

Waste or cultivated ground. A tall grass easily recognized by its velvety leaves.

Texas prairies.

Paspalum Hallii Vasey and Scribn. (P. pubiflorum Rupr.)

Moist soil along roadsides.

East Texas and Louisiana.

Paspalum stramineum Nash.

Roadsides, etc.

Southern-central states.

Syntherisma sanguinale Dulac. (Panicum sanguinale L.) Crab Grass. Finger Grass.

Cultivated grcund.

Introduced from Europe. Widespread in North America.

Tribe Oryzeae

Homolocenchrus oryzoides Poll. Rice Cut Grass.

Waller Creek.

Widespread in North America, Europe, and Asia.

\section{Tribe Phalarideae}

Phalaris caroliniana Walt. Canary Grass. Southern Canary Grass. Moist soil. Abundant in the flood plain of Waller Creek.

Southern states: South Carolina to California.

\section{Tribe Agrostideae}

Alopecurus geniculatus L. Meadow Foxtail. Water Foxtail.

In wet soil. Rare here.

Widespread in central and eastern states.

Aristida longiseta Steud. Needle Grass. Triple Awn Grass.

Abundant in dry ground. University campus.

From Washington and Montana to Texas and Mexico.

Aristida purpurea Nutt. Needle Grass. Triple Awn Grass.

Abundant in dry ground. University campus, etc.

Southern-central states.

Sporobolus vaginaeflorus Torr. Southern Poverty Grass. Sheathed Rush Grass. Porcupine Grass.

Common on roadsides in dry places. University campus.

Eastern and central states. 
Stipa leucotricha Trin. Needle Grass. Awn Grass. Porcupine Grass.

Abundant in dry fields, roadsides or open woods. University campus, etc.

Texas.

\section{Tribe Aveneae}

Trisetum interruptum Buckl.

Dry soil. University campus, etc.

Texas.

\section{Tribe Chlorideae}

Atheropogon curtipendulus Tourn. (Bouteloua curtipendula Torr.) Tall Mesquite Grass. Side Oats. Grama Grass.

Common in dry soil. University campus, etc.

Common in the prairie states and eastward.

Bouteloua hirsuta Lag. (B. hirta Scribn.) Hairy Grama Grass.

Black Grama Grass. Mesquite Grass.

Dry ground.

Prairies of the central states.

Boutelou trifida Thurb. Mesquite Grass.

Dry hillsides.

Texas and Arizona.

Bulbilis dactyloides Raf. Buffalo Grass.

Dry ground. University campus, etc.

Plains and prairies of the central states.

Capriola dactylon Kuntze. Bermuda Grass.

Abundant everywhere. Used extensively for lawns.

Naturalized from Europe. Abundant in the southeastern states.

Chloris cucullata Bisch.

Gravelly soil.

Texas.

Chloris tenuispica Nash.

University campus, etc.

Texas.

Chloris verticillata Nutt. Windmill Grass.

Dry soil. University campus, etc.

Arkansas to Kansas and Texas. 
Eleusine indica Gaertn. Yard Grass. Crab Grass. Wire Grass. Goose Grass.

Waste places.

Throughout almost the whole of North America.

Leptochloa mucronata Kunth. Feather Grass.

Abundant locally in meadows.

Southern states.

Polyodon texanus Nash. (Bouteloua texana S. Wats.) Texas Grama Grass.

Abundant on dry hillsides.

Texas and Oklahoma.

Tribe Festuceae

Bromus secalinus L. Chess, Cheat.

Roadsides and waste places.

Naturalized from Europe. Widespread in North America.

Bromus purgans texensis Shear.

Bluffs of the Colorado River. Moist soil.

Texas.

Bromus unioloides HBK. Rescue Grass. Brome Grass. Arctic Grass.

Common everywhere. University campus, etc. Waste and cultivated ground. One of the first grasses to bloom in the spring.

Southern states and Mexico.

Eragrostis capillaris Nees. Lace Grass. Tiny Love Grass.

Dry woods.

Eastern and central states.

Eragrostic pilosa Beauv. Hairy Spear Grass. Slender Meadow Grass. Widespread in eastern United States. Introduced from Europe.

Eragrostic secundiflora Presl. (E. interrupta Trelease.) Clustered Love Gràss.

Central states and Mexico.

Dry woods.

Erioneuron pilosum Nash.

Abundant on dry rocky hillsides.

Southern-central states. Kansas to Nevada and south to Mexico.

Festuca octoflora Walt. Slender Fescue Grass.

Abundant in dry and waste roadsides, along railroad tracks, etc.

Widespread in North America, more abundant in the southern states. 
Melica mutica Walt. Narrow Melic Grass.

Colorado River bluffs at Deep Eddy, in rich moist soil.

Eastern and central states.

Poa annua L. Annual Poa.

Abundant in waste and cultivated grounds. The first grass to bloom in the spring or winter.

Naturalized from Europe. Found throughout nearly the whole of North America.

Poa arachnifera Torr. Texas Blue Grass.

Moist ground in the valley of Shoal Creek.

Southern-central states.

Rhombolytrum albescens Nash. (Sieglingia albescens Kuntze.) White Prairie Grass.

Along the I. \& G. N. Railroad.

Prairies of the southern-central states.

Tridens albescens W. \& S. (Triodia albescens Bent.; Tricuspis albescens Munro).

Prairies of southern Texas and New Mexico. Kansas to Texas, and New Mexico.

Tridens muticus Nash. (Sieglingia mutica Kuntze.)

Dry hillsides. Mt. Bonnell.

Texas to Arizona and in northern Mexico.

Uniola latifolia Michx. Wild Oats. Broad-leaved Spike Grass.

Moist soil. Rich soil of shaded river bluffs.

Eastern and central states.

\section{Tribe Hordeae}

Elymus canadensis L. Wild Rye. Lyme Grass.

Moist ground. Shoal Creek Valley, etc.

Central states.

Hordeum pusillum Nutt. Wild Barley.

Agundant in dry soil, waste and cultivated places.

Central states, Wyoming and California.

Lolium perenne L. Rye Grass.

Rare here.

Naturalized from Europe. Widespread in the United States. 


\section{CYPERACEAE, Sedge Family}

\section{Carex amphibola Steud.}

Hillsides and ravines of the Edwards Plateau.

Eastern and central states.

Carex cherokeensis Schwein.

Moist ground along stream. Bee Creek.

Southern states.

Carex triangularis Boeckl.

Low ground, Shoal Creek Valley, etc.

Scuthern central states.

Cyperus ferax Vahl.

Wet soil. Barton Springs.

Warm and tropical regicns of America.

Cyperus filiculmis Vahl.

Dry woods.

Central and southern states and northern Mexico.

Cyperus rotundus L. Nut-grass.

Abundant in lawns and roadsides in Austin. A serious pest.

Southern states and tropical America.

Dichromena colorata Hitchcock. Whitetop.

Not abundant here.

Coastal plain states from New Jersey to Texas.

Dichromena nivea Boeckl. Whitetop. A smaller species than the preceding.

Abundant along the borders of streams and in swampy ground along railroad tracks. Barton Creek.

Southern states and the tropies.

Fuirena simplex Vahl. Western Umbrella-grass.

Wet soil. Barton Springs, Shoal Creek, etc.

Nebraska, Texas, and Mexico.

Scirpus validus Vahl. Bullrush.

Swamps. Not common here.

Widely distributed throughout North America. 


\section{ARALES}

\section{ARACEAE Arum Family}

Muricauda Dracontium Small. (Arisaema dracontium Schott.) Green

Dragon. Dragon Root.

Moist rich soil on shaded bluffs of the Colorado River and Bull Creek.

Eastern and Central states.

\section{LEMNACEAE Duckweed Family}

Lemna cyclostasa Chev.

Waller Creek. Similar to the following but obscurely one nerved plant, body oblong or nearly so.

Widespread in the United States. Also in Jamaica and South America.

Lemna minor L. Duckweed.

Abundant in stagnant pools and in still water of creeks, forming a green scum over the water. The plant is a thin disk-like body about $4 \mathrm{~mm}$. in diameter with a single root. From oval to nearly circular with a papillate midrib.

Widespread over almost the whole of North America.

\section{XYRIDALES}

\section{COMMELINACEAE Spiderwort Family}

Commelina angustifolia Mich.(?)

Commelina crispa Wooton. Curly-leaved Day-flower. Leaves crisped. Rocky hillsides.

Southern central states.

Commelina erecta L. Day Flower.

Southeastern United States and tropical America.

Commelina virginica L. Day Flower.

Moist hillsides.

Central and southeastern United States and tropical America.

Tradescantia gigantia Rose. Spiderwort.

Fields and roadsides.

A tall, erect species with a stout stem two or three feet high.

Tradescantia occidentalis Brit. Spiderwort.

Rocky hillsides.

Central states to the Rocky Mountains. 
Tradescantia.

A form similar to $T$. virginiana.

\section{PONTEDERIACEAE Pickerel-Weed Family}

Heteranthera dubia McM. (H. graminea Vahl.) Water Star-grass. In Barton Creek. Submerged, but with its yellow flowers exserted. Widespread throughout the United States in still water.

\section{BROMELIACEAE Pine-Apple Family}

Dendropogon usneoides Raf. (Tillandsia usneoides L.) Spanish Moss. Long Moss. Florida Moss.

Abundant on trees in ravines, as the valleys of Shoal Creek and Waller Creek where the air is more moist than on the uplands. Pendent in long festoons from the branches of the trees.

Southern states and Central America. More common near the coast.

Tillandsia recurvata L. Ball Moss.

Abundant on trees on the uplands; growing in small tufts; no: pendent.

Texas, Mexico and tropical America.

\section{LILIALES}

\section{MELANTHACEAE (Under Liliaceae) Bunch-Flower Family}

Schoenocaulon Drummondii A. Gray.

Dry soil, roadsides and hillsides in open places.

A prairie plant of Texas and Mexico.

Toxicoscordion Nuttalii Rydb. (Zygadenus Nuttalii S. Wats.)

Level uplands of the Edwards Plateau.

A prairie plant of the southern central states.

\section{JUNCACEAE Rush Family}

Juncus dichotomus Ell. Rush.

Wet ground.

Mostly near the coast. Massachusetts to Texas.

\section{ALLIACEAE (Under Liliaceae) Onion Family}

Allium canadense L. Meadow Garlic.

Moist ground, flood plain of Onion Creek. Most of the flowers are replaced by bulblets.

Eastern states. 
Allium Helleri Small. (A. Nuttalii Wats.) Wild Onion. Garlic.

Abundant in open ground. One of our conspicuous spring wild flowers, with beautiful pink or sometimes white flowers. Stems usually $1-2 \mathrm{dm}$. tall.

Dry prairies of the west central states.

Allium microscordion Small. Wild Onion.

2-4 dm. tall. Pink.

Southern states.

Allium mutabile. Wild Onion.

Open ground along railroad tracks and where the soil is deep. $2-5 \mathrm{dm}$. tall. White (or pink).

Soutsern states.

Androstephium coeruleum Greene. (A. violaceum Torr.)

In open ground along railroad tracks and on dry banks. The large blue flowers have the filaments of their stamens united into a tube attached to the pehianth. Not abundant.

A prairie plant occurring from Kansas to Texas.

Nothoscordium bivalve Britton. (N. striatum Kunth.) Crow-poison. False Garlic.

Common everywhere about Austin. One of our early wild flowers. Very similar to a wild onion, but without the onion odor.

Southeastern and central states and Mexico.

\section{LILIACEAE Lily Family}

Quamasia hyacinthifolia Britton. (Camassia Fraseri Torr.) Wild Hyacinth.

Abundant along railroad tracks and in other open ground where the soil is deep. An elongated cluster of blue or white flowers. One of our conspicuous spring wild flowers.

Central and southern states.

\section{DRACAENACEAE Yucca Family (Under Liliaceae)}

Nolina Lindheimeriana S. Wats. Slender Bear Grass.

Rocky bluffs of the Edwards Plateau. Somewhat like a Yucca, but with much more grass-like leaves.

A characteristic plant of the dry rocky regions of West Texas and New Mexico.

Nolina texana Wats. (Not given in Small.*) Slender Bear Grass.

Very common on the rocky bluffs of the Edwards Plateau. Similar to the preceding.

Characteristic of the dry hills of West Texas.

*Small's Flora of the Southeastern United States. Published and for sale by J. K. Small, Bronx Park, New York City, New York. 
Yucca rupicola Scheele. Spanish Bayonet. Bear Grass.

Abundant on dry hills. The leaves are margined by a row of fine yellow teeth.

Yucca Arkansana Trelease.

Smaller than the preceding. The leaves have white-fibrous margins. Dry ground along I. \& G. N. railroad tracks.

Southern prairie states.

\section{SMILACEAE Smilax Family (Under Liliaceae)}

Smilax Bona-nox L. Green-briar. Cat-briar. Stretch-berry.

Very common in woods and thickets. A climbing prickle armed vine.

Southeastern United States to Kansas and Mexico.

\section{AMARYLLIDALES (Under Liliales)}

\section{LEUCOJACEAE (Amaryllidaceae) Amaryllis Family}

Atamosco texana Greene. (Zephyranthes texana Herb.) Atamosco Lily. Stagger Grass. Amaryllis.

In the open post-oak woods. Not very common. Flowers yellow, stems about 1 to $2 \mathrm{dm}$. high. Insane Asylum grounds and in dry rock soil generally.

Cooperia pedunculata Herb. Rain Lily.

Abundant in open places, blooming several days after a rain. This species blooms more commonly in the spring. The flowers are white.

The bract is attached about one-fourth inch below the ovary.

A plant of the Texas prairies.

Cooperia Drummondii Herb. Rain Lily.

Similar in habit and habitat to the preceding species, but blooming more abundantly in the fall. Flowers smaller, stems and leaves more slender and the bract is attached immediately below the ovary.

Texas prairies.

\section{IXIACEAE (IRIDACEAE) Iris Family}

Nemastylis acuta Herb.

Abundant on dry hillsides and level uplands of the Edwards Pla. teau. The flowers are four or five centimeters in diameter, from deep blue to white.

A prairie plant of the southern central states. 
Sisyrinchium pruinosum Bicknell. Blue-eyed Grass.

A tufted, grass-like plant. The deep blue flowers have yellow centers.

Abundant in meadows and roadsides.

A plant of the north Texas prairies.

Sisyrinchium minus Engelm. and Gray.

In low places along railroad tracks and roadsides where the soil is fine and compact. A low form with small reddish flowers.

Characteristic of low moist prairies of east Texas and Louisiana. Sisyrinchium, other species, not certainly identified.

\section{ORCHIDALES}

\section{ORCHIDACEAE Orchid Fiamily}

Ibidium (Spiranthes, gyrostachys). Ladies' Tresses.

Hillsides of the Edwards Plateau.

Flowers small, white, in racemes about four inches high.

\section{DICOTYLEDONS}

\section{JUGLANDALES}

\section{JUGLANDACEAE Walnut Family}

\section{Hicoria Pecan Britton. Pecan.}

On the river flood plain and in most valleys. Abundant along Walnut Creek.

Southern-central states and introduced eastward.

Juglans nigra L. Black Walnut.

A large tree with a fruit an inch or more in diameter.

River flood plain and deep ravines. Abundant along Walnut Creek.

Widespread in the eastern and central forest regions of the United States.

Juglans rupestris L. Mexican Walnut.

Small trees. Ravines of the Edwards Plateau. The nut is about $1 \mathrm{~cm}$. in diameter.

Texas, New Mexico and Mexico. Common along streams in the arid mountain regions of West Texas. 


\section{SALICALES}

\section{SALICACEAE Willow Family}

Populus deltoides Marsh. (P. monilifera Ait.) Cottonwood.

River flood plain.

Central North America from Canada to Texas and New Mexico.

Salix nigra Marsh. Black Willow.

Along the river banks.

\section{FAGALES}

\section{FAGACEAE Beech Family}

Quercus breviloba Sargent. Shin Oak. White Oak.

Rocky banks along streams.

Forming thickets ("shinneries") in the Edwards Plateau region. Can be recognized by the bark which peels off in thin sheets.

Confined chiefly to middle and southern Texas.

Quercus fusiformis Small. Mountain Live Oak.

Dry hillsides of the Edwards Plateau. An evergreen shrub or small tree, with very smooth, slender branches.

Central Texas, probably derived from $Q$. virginiana.

Quercus macrocarpa Michx. Bur Oak.

Walnut Creek. The acorns are very large and the cups are fringed. Eastern North America.

Quercus marilandica Muench. Black Jack.

Gravelly uplands. Abundant on the terrace gravels with Q. Minor.

Southern and eastern to the central states. More abundant in the South. Characteristic of sandy and gravelly soils in Texas with Q. minor. Leaves angular deep green and glossy. Bark blackish.

Quercus minor Sarg. (Q. stellata Wang.) Post Oak.

Gravelly uplands. Abundant on the terrace gravels with Q. marilandica.

Southern and eastern central states, more abundant in the South. This tree occurs in Texas with Q. marilandica in the "post oak" forests in the sandy and gravelly soils of the eastern part of the state west of the pine area.

Quercus schneckii Britton. (Q. texana Sarg., not Buckl.) Red Oak. Ravines and hillsides. Chiefly in the Edwards Plateau. Leaves glossy, deeply lobed and with sharp pointed teeth.

Southeastern states. 
Quercus virginiana Mill. Live Oak.

Abundant in low ground and hillsides. Our common evergreen oak.

Characteristic of the coastal regions from Virginia to Mexico.

\section{URTICALES}

\section{URTICACEAE Nettle Family}

Boehmeria cylindrica Willd. False Nettle.

Moist ravines. Nettle-like, but without stinging hairs.

Eastern and central North America.

Parietaria obtusa Rydb. Pellitory.

Very abundant in moist soil on shaded banks and hillsides. Leaves ovate or ovate-oblong with relatively long petioles. Involucral bracts oblong obtuse. Sepals ovate, usually acute at the apex.

West-central states.

Parietaria pennsylvanica Muhl. Pellitory.

Shaded ground. Leaves usually lanceolate, with shorter petioles than the preceding. Involucral bracts linear. Sepals oblong or lanceolate, acute.

Urtica chamaedryoides Pursh. Nettle.

Abundant in moist ravines and thickets. Well known for its stinging hairs.

Southeastern United States.

\section{ARTOCARPACEAE (MORACEAE) Mulberry Family}

Broussonetia papyrifera Vent. White Mulberry. Paper Mulberry. Low ground. A common shade tree in Austin. Like a mulberry, but with thick, velvety leaves.

Introduced from Asia. Eastern and southern states.

Morus microphylla Buckl. Small-leaved Mulberry. Mexican Mulberry.

Ravines of the Edwards Plateau. A shrub or small tree. Leaf blades 3 to $5 \mathrm{~cm}$. long. Fruit 1 to $1.5 \mathrm{~cm}$. long.

Western Texas to Arizona and northern Mexico.

Morns mibra L. Red Mulberry.

In moist ravines of the Edwards Plateau. Leaf blades 6 to $20 \mathrm{~cm}$. long. Fruit 3 or more $\mathrm{cm}$. long.

Eastern United States. 
Toxylon pomiferum Raf. Bois D'Arc. Bowwood. Osage Orange.

Low ground. Ravines and valleys.

Southeastern states.

\section{ULMACEAE Elm Family}

Celtis mississippiensis Bosc. Hackberry.

Very common on hills and in ravines. The most common shade tree in Austin.

Central and southeastern states.

Celtis reticulata Torr. Hackberry.

On dry hills. Similar to the preceding, but with rough leares and large berries.

A species of the arid southwest. In western Texas it occurs near streams.

Ulmus alata Michx. Winged Elm. Cork Elm. Wahoo.

Abundant in ravines and valleys. Easily recognized by the conspicuous corky wings on the branches. Flowering in spring.

Southern states.

Ulmus americana L. White Elm.

On the river flood plain and in ravines. Differing from the other species in its large, thin leares. Used as a shade tree. Flowering in spring.

Eastern United States.

Ulmus crassifolia Nutt. Cedar Elm.

Abundant in ravines and uplands. A common shade tree in Austin flowering in the fall. Leaves leathery, blades $3-6 \mathrm{~cm}$. long.

Along rivers in the southern central prairie states.

\section{POLYGONALES}

\section{POLYGONACEAE Buckwheat Family}

Eriogonum longifolium Nutt.

Dry ground.

Southern central states.

Persicaria hydropiperoides Small. (Polygomum hydropiperoides Michx.) Wild Water-pepper.

Ditches and along streams.

Widespread in North America. 
Persicaria lapathifolia S. F. Gray. (Polygonum lapathifolium L.) Willow Weed.

Low ground, waste places.

Naturalized from Europe. Widespread in North America.

Persicaria pennsylvanica Small. (Polygonum pennsylvanicum L.) Smart Weed.

River bank. With dense cylindrical racemes of pink flowers.

Eastern North America and in Mexico.

Persicaria punctata Small. (Polygonum punctatum Elll.) Smart Weed.

River bank, Barton Creek, etc. With loosely flowered racemes of small greenish flowers.

Widespread in North America.

Persicaria setacea Small. (Polygonum setaceum Baldw.)

Waller Creek.

Eastern United States.

Polygonum erectum L.

River bank. In open ground.

Ontario to the Northwest Territory, Georgia, Colorado, and Texas.

Polygonum ramosissimum Michx. Bushy Knotweed.

Roadsides.

Rumex altissimus Wood. Peach-leaved Dock. Pale Dock.

Low wet ground. Abundant in Shoal Creek Valley. Two to four feet tall.

Northwestern and central states.

Rumex Berlandieri Meisn(?)

Waste places. A form with slender, spreading branches. Flowers in dense whorls separated on the branches.

Texas to Arizona and in Mexico. Western North America.

Rumex crispus L. Curl Dock.

Low wet ground. Abundant in Shoal Creek Valley. One to three feet tall; leaves with edges crisped.

Naturalized from Europe. Widespread in North America.

Tiniaria convolvulus Webb and Moq. (Polygonum convolvulus L.) Black Bind-Weed.

University campus. A twining vine with the aspect of a morning glory. Not common here.

Naturalized from Europe. Widespread in North America. 


\section{CHENOPODIALES}

\section{CHENOPODIACEAE Goosefoot Family}

Chenopodium album L. Lamb's Quarter.

Waste places in cultivated ground. This Chenopodium can be recognized by its mealy leaves.

Widespread in North America. Introduced from Europe.

Chenopodium anthelminicum L. Wormseed.

River banks, and waste places. Easily recognized by its disagreeable order when bruised.

Atlantic and Gulf States. Introduced from Europe.

Chenopodium Boscianum Moq. Bosc's Goosefoot.

Low ground, waste places.

Eastern United States.

Chenopodium Fremontii S. Wats. (Not in Small.) Fremont's Goosefoot.

Waste places.

Central states to Mexico.

Monolepsis Nuttaliana Greene. (M. chenopodioides Nutt.)

Common in waste ground.

Western and central states.

\section{AMARATHACEAE Amaranth Family}

Alternanthera repens Kuntze.

Abundant in waste places.

South America and southern states.

Amaranthus albus L. (A. graecizans L.) Tumble Weed.

Waste places.

A tropical American species widely distributed in North America.

Amaranthus blitoides Reverchonii Uline and Bray. Low Amaranth.

Pigweed.

Waste places.

Central Texas.

Amaranthus Palmeri S. Wats. Amaranth. Pigweed.

Waste and cultivated ground. Roadsides, etc.

Southwestern states and Mexico. 
Amaranthus Pringlei Watson. (Not given in Small.) Amaranthus. Pigweed.

Fields and roadsides.

West Texas, southern plains states to Mexico.

Amaranthus retroflexus L. Amaranth. Rough Pigweed.

Roadsides and waste places.

Naturalized from the American tropics. Widespread in North America.

Amaranthus spinosus L. Spiny Amaranth.

Roadsides and waste places.

Naturalized from the American tropics. Widespread in eastern and southern United States.

Brayulinea densa Small. (Guilleminea densa Moq.)

Dry ground.

New Mexico, Texas and Mexico to tropical America.

Celosia paniculata L.

Bluffs. Barton Creek. Not abundant.

Florida, Texas and Mexico.

Froelichia campestris Small.

Abundant in dry ground, post oak woods, etc.

Prairie and pains states.

Gossipianthus lanuginosus Moq.

Dry ground.

Oklahoma to Mexico.

CORRIGIOLACEAE Whitlow-wort Family (Illicebraceae)

Paronychia dichotoma Nutt. Forking whitlow-wort. Nailwort. Dry exposed bluffs. Mt. Bonnell.

Southeastern states.

P. Lindheimeri Englem.

In dry soil.

Texas and New Mexico.

PETIVERACEAE (PHYTOLACCACEAE) Poke-weed Family

Rivina humilis $\mathrm{L}$.

Common in rich soil. University campus, Shoal Creek, etc.

Southeastern states and tropics. 
Phytolacca decandra L. Poke-berry. Poke-weed.

Common in the river flood plain.

Widespread in the eastern United States.

\section{ALLIONIACEAE (NYCTAGINACEAE) Four-o'clock Family}

Allionia albida Walt. Umbrella-wort.

Roadsides, etc.

Southeastern states.

Allionia nyctaginea Michx. Umbrella-wort.

Dry ground. Roadsides, etc.

Plains and prairie states.

Boerhaavia decumbens Vahl.

Dry ground. Roadsides, etc.

Gulf states and Mexico.

Boerhaavia erecta L.

Dry ground, roadsides, etc:

Gulf states, Mexico and the tropics.

Mirabilis Jalapa L. Four o'clock.

In waste places and cultivated soil.

Central and South America to Texas.

\section{TETRAGONIACEAE (AIZOACEAE) Carpet-weed Family}

Mollugo verticillata L. Carpet-weed. Indian Chickweed.

Cultivated ground and waste places.

\section{PORTULACACEAE Purslane Family}

Claytonia virginica L. Spring Beauty.

Moist shaded ground at the base of bluffs on Onion Creek. A low plant with fleshy linear leaves from a tuber-like corm. The flowers are a light pink, delicately veined with a darker shade.

Eastern states.

Portulaca lanceolata Engelm.

Occasional here. Found in the Asylum grounds and near Barton Creek. Easily recognized by the crowned capsule.

From Texas to Arizona.

Portulaca oleracea L. Pursley.

Cultivated ground. Ramsey's Nurseries, etc.

South America and almost throughout North America. 
Portulaca pilosa L.

Abundant on dry hills. Our most common Portulaca, recognized easily by the tufts of hairs in the axils of the leaves.

Southern states and Mexico.

Talinum aurantiacum Engelm.

Pease place.

Texas, New Mexico, and in Mexico.

Talinum parviflorum Nutt.

Dry soil. Postoak woods.

Central states.

\section{ALSINACEAE Chickweed Family (Under Caryophyllaceae)}

Alsine Baldwinii Small. (Stellaria prastrata Baldw.) Chickweed.

Starwort.

Abundant in moist ground in ravines of the Edwards Plateau.

Gulf states and in Mexico.

Alsine media L. (Stellaria media Smith.) Chickweed.

Moist ground. Abundant in Shoal Creek Valley.

Widespread in North America and Europe.

Arenaria Benthamii Fenzl. Sandwort.

Abundant on hillsides. Mt. Bonnell, etc.

Texas.

Cerastium brachypodium Robinson. Mouse-ear Chickweed.

Pastures, meadows, and open woods.

Central states.

Cerastium longipedunculatum Muhl. Powder Horn.

Moist ground, pastures and woods.

Widespread in North America.

Cerastium viscosum L. Mouse-ear Chickweed.

Roadsides and hillsides.

Eastern United States; naturalized from Europe.

Sagina decumbens T. \& G. Pearlwort.

Abundant in the compact soil of Postoak woods.

Eastern United States. 


\section{CARYOPHYLLACEAE Pink Family}

Silene antirrhina L. Sleepy Catchfly.

Abundant on roadsides, University campus, etc. Easily recognized by the sticky secretions on the stems in which very small insects become entangled and die.

Widespread in the eastern part of the continent.

\section{RANALES}

\section{CERATOPHYLLACEAE Hornwort Family}

Ceratophyllum demersum L. Hornwort.

Barton Creek. A submerged acquatic plant, with stiff, finely divided leaves in whorls.

Nearly throughout North America.

\section{RANUNCULACEAE Crowfoot Family}

Adonis annua L.

Waste and cultivated ground.

Introduced from Europe and escaped from cultivation in the United States.

Anemone decapetala Ard.

Open woods and meadows. Abundant in valleys. One of our most abundant early spring flowers.

Central and southern states. Central America and Mexico.

Aquilegia canadensis L. Red Wild Columbine.

Moist shaded bluffs in the Edwards Plateau, in ravines where the soil is rich. One of the most beautiful flowers of the region. Abundant along Bull Creek and its tributary ravines.

Widespread in the northern and eastern states.

Aạuilegia chrysantha Gray. Yellow wild Columbine.

Moist shaded slopes in the Bull Creek region. Less common than the preceding. The flowers are yellow and the spurs of the petals are more than two inches long.

Arizona to Texas. Common in moist ravines in the mountains of Western Texas.

Clematis Drummondii T. \&. G. Virgin's Bower. Granddaddy Gray beard.

A vine, abundant on roadsides and open places, particularly on the river flood plain. Well known in the fall for its white plumed fruits.

Texas to Arizona and in Mexico. 
Delphinium albescens Rydb. White Larkspur.

Open woods, roadsides, etc.

Central States.

Delphinium carolinianum Walt. Blue Larkspur.

Open woods, roadsides, etc.

Southeastern states.

Myosurus minimus L. Mouse-tail.

Wet places. A very small plant resembling an anemone, but with sepals and petals, the sepals spurred. The great elongation of the axis bearing the carpels in fruit gives the plant its popular name.

Eastern states.

Ranunculus macranthus Scheele. Buttercup, Crowfoot.

In mcist soil along streams. Shoal Creek, Barton Creek, etc. The flowers more commonly called buttercup here belong to the evening primrose family.

Texas.

Viorna coccinea Small. (Clematis coccinea Engelm.)

Moist ground along streams and in deep moist ravines.

Very common along Bull Creek and Onion Creek. One of the most beautiful flowers of our region. A vine with large drooping crimson blossoms. The three perianth parts are very thick and somewhat leathery.

Texas.

Visrna reticulata Small.

Similar to $V$. cocinea but the flowers dull purple. Occasional in thickets.

Southeastern states.

\section{MENISPERMACEAE Moonseed Family}

Cebatha caroliniana Britton. (Cocculus carolinus D.C.) Coral Bead. A very common vine in open woods and thickets and in fence rows. Conspicuous in the fall for its beautiful cluster of scarlet berries. Southern states.

\section{PODOPHYLLACEAE (Berberidaceae) Barberry Family}

Berberis trifoliolata Moric. Agarita. Chaparral.

A bush abundant on hillsides and in woods. Well known by its prickle-pointed, holly-like leaves and scarlet berries. A "chaparral" plant.

Texas and Mexico. 


\section{PAPAVEVRALES}

\section{PAPAVERACEAE Poppy Family}

Argemone alba Lesteb. Wild Poppy.

Open dry ground, with large white flowers and prickly leaves and stems.

Southeastern states.

Argemone Platyceras Link \& Otto. Wild Poppy.

Open dry ground. Similar to the preceding.

Southwestern states and Mexico.

\section{Papaver dubium L. Poppy.}

Growing wild abundantly on the campus. The familiar red poppy. Introduced from Europe and growing wild in the eastern states

\section{FUMARIACEAE Fumitory Family (Under Papaveraceae)}

Capnoides curvisiliquum Kuntze. (Corydalis curvisiliqua Engelm.) Very common in open woods and valleys. Blooming early with bright yellow, irregular flowers in elongated clusters.

Kansas to Texas.

\section{BRASSICACEAE (CRUCIFERAE) Mustard Family}

Arabis petiolaris A. Gray.

Common in open woods and uplands of the Edwards Plateau.

Plains and prairies of southwestern Texas.

Arabis virginica Trelease. (A. ludoviciana Meyer.) Virginia Rock Cress.

Abundant in the early spring in wet places along roadsides and ir shallow pools.

Eastern and southern states.

Brassica Juncea Cosson. Indian Mustard.

Found in an alfalfa field and presumably introduced with the seed.

Naturalized from Asia. Widespread in the northeastern states.

Bursa Bursa-pastoris Brit. (Capsella bursa-pastrris Moench.) Shepherd's Purse.

Abundant in waste and cultivated ground, lawns and roadsides. Well known by its triangular or heartshaped pods.

Native of Europe, but widely distributed all over the world. One of the commonest weeds in the world. 
Draba cuneifolia Nutt. Whitlow Grass.

Waste and cultivated ground, lawns, and roadsides. Abundant everywhere. One of the first flowers to bloom in the spring. A low herb with fuzzy leaves and a cluster of small white blossoms. The pods are flattened and oval.

Illinois to the Gulf States and California.

Draba platycarpa T. \&. G. Whitlow Grass.

Verly similar to the preceding species in appearance and hat itat. Abundant everywhere.

Texas to Arizona.

Lepidium austrinum Small. Peppergrass.

Waste places and cultivated ground. Roadsides.

Texas.

Lepidium apetalum Wild. Green-flowered. Peppergrass.

Waste places and roadsides.

Widespread in North America.

Lepidium medium Greene. Peppergrass.

Roadsides and open woods. Very common in the postoak woods. Blooming early and at first very small.

Widespread in the western half of the continent.

Lepidium virginicum L. Common Peppergrass.

Fields and roadsides.

Widely distributed ir. the central and eastern states and in Mexico.

Lesquerella densiflora S. Wats. Bladder-pod.

Dry or moist soil. The Lesquerellas can be recognized by their spherical pods.

Texas.

Lesquerella Engelmannii S. Watts. Bladder-pod.

Abundant on the dry hillsides of the Edwards Plateau.

Kansas to Colorado and Texas.

Lesquerella gracilis S. Wats. Slender Bladder-pod.

Dry soil.

Nebraska to Texas. A prairie plant.

Lesquerella lasiocarpa S. Wats. Bladder-pod.

Texas and Mexico.

Lesquerella grandiflora S. Wats. Large-flowered Bladder-pod. Open ground. Abundant on the river flood plain.

Texas. 
Lesquerella recurvata S. Wats. Bladder-pod.

Common everywhere in exposed places, dry hillsides, roadsides, and open woods. Our most common species.

Texas.

Roripa Nasturtium Rusby. (Nasturtium officinale R. Br.) Water Cress.

Abundant in Barton Creek and other streams.

Naturalized from Europe and widely distributed in this country.

Roripa abtusa Brit.

Found near the river.

Widely distributed.

Sophia millefolia Rybd.

Waste ground, roadsides.

Kentucky to Texas.

Sisymbrium canescens var. brachycarpa Watt. (S. brachycarpa Richards.

Waste places.

Southeastern states.

Streptanthus bracteatus A. Gray.

Dry soil.

Southwest Texas.

Streptanthus platycarpus A. Gray.

River flood plain.

Texas and Mexico.

\section{CAPPARIDACEAE Caper Family}

Polanisia gravoeolens Raf. Clammy Weed.

Dry, waste ground. A homely weed with a heavy, disagreeable odor. Very similar to the following species.

Northern states.

Polanisia trachysperma T. \& G. Clammy Weed.

Dry waste ground-a very common weed. Illscented.

Central and west central states. 


\section{ROSALES \\ SEDACEAE (CRASSULACEAE) Orpine Family}

Sedum Nuttalianum Ref. Stonecrop.

Very abundant on level rock uplands of the Edwards Plateau and in dry gravelly soil of the postoak woodlands. A small succulent annual, rooting in very shallow soil and disappearing during the dry season. When in bloom its yellow flowers form a conspicuous covering in shallow depressions in the rocks.

South central states.

Sedum pulchellum Michx. Stonecrop. Rock Moss.

Hilltops of the Edwards Plateau region. A little larger than the preceding and with white flowers. Rather rare.

Southeastern states.

Tilleastrum Drummondii Britton (Tillaea Drummondii T. \& G.)

Common on shallow pools and mud holes of the postoak woods. Disappearing in the dry season. A minute plant with reddish succulent stems.

Western states and Mexico.

\section{SAXIFRAGACEAE Saxifrage Family}

Lepuropetalon spathulatum Ell.

In compact wet soil of the postoak woods. Disappearing in the dry season. A very tiny, short-stemmed plant with yellowish blossoms.

Southeastern states and Mexico.

\section{PLATANACEAE Plane-tree Family}

Platanus occidentalis L. Sycamore.

A familiar shade tree. Growing wild along streams.

Widespread in eastern North America.

\section{ROSACEAE Rose Family}

Geum canadense Gmel. Avens.

In moist, rich soil. Shaded bluffs Onion Creek.

Northeastern states.

Geum Virginianum L. Avens.

Moist woods north of the Seminary.

Eastern states and Canada.

Rubus trivialis Michx. Dewberry.

Abundant in waste ground, along railroad tracks and roadsides.

Southeastern states. 


\section{MALACEAE Apple Family (Under ROSACEAE)}

Crataegus sp. Hawthorne.

In thickets in rich woods; and on the banks of streams. Not common, except in gravelly soil east of Hyde Park.

\section{AMYGDALACEAE Plum Family (Under ROSACEAE)}

Prunus americana Marsh. Wild Yellow Plum. Red Plum. Moist ravines.

Widespread in the eastern and central states.

Prunus angustifolia Marsh. Chickasaw Plum.

Thickets.

Southeastern states.

Padus serotina Agardh. (Prunus serotina Ehrh.) Black Cherry. Wild Cherry.

Moist ravines.

Eastern and central states.

\section{MIMOSACEAE Mimosa Family (Under Legumimosae)}

Acacia filicoides Trelease.

Waste ground.

Southern central states.

Acacia Roemeriana Schlecht.

Hills of the Edwards Plateau. In dry soil. A spiny schrub.

Southern Texas and Mexico.

Acuan Illinoensis Kuntze. (Desmanthus brachylobus Benth.)

Dry soil. A low plant without thorns.

Central and Gulf states.

Acuan velutina Kuntze. (Desmanthus velutinus Scheele.)

Dry, poor soil, roadsides, etc. A prostrate plant without thorns. Southern and western Texas.

Mimosa fragrans A. Gray. Cat Claw.

Very common thorny shrub in the dry hillsides of the Edwards Plateau.

Morongia uncinata Britt. (Schrankia uncinata Willd.). Sensitive Briar.

Common on dry barren soil, along railroad tracks and roadsides. Prostrate, its long, slender branches armed with prickles. 
Prosopis glandulosa Torr. (P. juliflora var. glandulosa Sarg.) Mesquite.

Abundant almost everywhere. Our most common tree.

Spreading from the southwest over the prairies of Texas.

\section{CASSIACEAE Senna Family (Under Leguminosae)}

Cassia Lindheimeriana Scheele. Senna.

Abundant on the dry hills of the Edwards Plateau.

Texas to Arizona and in Mexico.

Cassia occidentalis L. Senna.

Occasional here.

Southern states and in Mexico.

Cassia Roemeriana Scheele. Senna.

Abundant on the dry hills of the Edwards Plateau.

Texas, New Mexico, and Mexico.

Cercis occidentalis Torr. Red-bud. Judas-tree.

Abundant in ravines and on hillsides of the Edwards Plateau. A small tree, conspicuous in the spring with its abundant pink blossoms. Peculiar in the production of flower clusters from buds on old branches.

Texas and Northern Mexico. Closely related to $C$. canadensis of the eastern states.

Gleditsia triacanthos L. Honey Locust.

A common shade tree in Austin. Growing wild on the river flood plains. A tree easily recognized by its branching thorns.

Eastern North America.

Parkinsonia aculeata L. Retama. Horsebean.

Abundant locally, on the river flood plain and in waste places, roadsides, etc.

Tropical America, Mexico, and from the Gulf States to California.

\section{KRAMERIACEAE Krameria Family (Under Leguminosae)}

Krameria secundiflora DC.

Common in dry ground along railroad tracks, etc. A nearly prostrate plant with irregular reddish purple blossoms.

Southeastern states and Mexico. 


\section{FABACEAE (LEguminosae) Pea Family}

Amorpha fruticosa L. False Indigo.

Along streams. A tall shrub with small, dark, purple flowers in large clusters. Growing close to the water at Barton Springs.

Southeastern states.

Amorpha texana Buckl. Fake Indigo.

Bull Creek region.

East Texas.

Astragalus reflexus T. \& G.

Abundant in dry ground, University campus, etc.

Texas.

Astragalus Wrightii AG.

Abundant in dry soil. University campus.

Texas.

Clitoria mariana L. Butterfly Pea.

A showy plant with large solitary flowers. The large standard of the corolla is striped with purple, the keel shorter than the wings. The leaves are 3 -foliate.

Occasional in the postoak woods.

Daubentonia longifolia D.C. (Sesbania Cavanillesii Wats.) Rattle Box. Rattle Bush.

Low open ground. Flood plain of the river. A shrub easily recognized by its flat four-sided and four-winged pods.

Mexico and the Gulf States.

Dolicholus texensis Vail. (Rhynchosia texana Torr. \& Gray.)

Dry grounds. University campus.

Texas to Arizona and in Northern Mexico.

Eysenhardtia amorphoides HBK. Rock-brush.

In dry woods and exposed hillsides. Abundant on the lower slopes in the Edwards Plateau. A low bush easily identified by its disagreeable odor when bruised.

Texas and Mexico.

Geoprumnon crassicarpum Rydb. (Astragalus crassicarpus Nutt.) Ground Plum.

Dry slopes of the Edwards Plateau. A prostrate plant with a large fleshy, plum-like pod.

Western plains and prairies. 
Geoprumnon Mexicanum Rydg. (Astragalus Mexicanus A. D.C.) Ground Plum.

Hills of the Edwards Plateau. Similar to the preceding. Prairie states.

Hamosa austrina Small.

Dry, open ground. Roadsides, University Campus.

Texas to California and in Mexico.

Hamosa leptocarpa Rydb. (Astragalus leptocarpus T. \& G.)

Dry open ground. University campus.

Texas.

Hamosa Lindheimeri Rydb. (Astragalus Lindheimeri Engelm.)

Dry hillsides.

Texas.

Hamosa Nuttaliana Rydb. (Astragalus Nuttalianus DC.)

Open, dry ground. University campus.

From Arkansas and Texas to Arizona.

Indigofera leptosepala Nutt. Indigo Plant.

Open, dry ground. Abundant on the University campus. The blossoms are orange-red.

Southeastern states and Mexico.

Lathyrus pusillus Ell. Low Vetchling.

Dry soil.

Southeastern states.

Lespedeza frutescens Brit. (L. Stuvei var intermedia S. Wats.)

Bush Clover.

Dry soil. In the post oak woodland.

Eastern Texas.

Lespedeza procumbens Michx. Bush Clover.

Eastern states.

Lotus americanus Bisch. (Hosackia Purshiana Benth.)

Dry soil. Post oak woods.

Plains states and Mexico.

Lupinus texensis Hook. Blue Bonnet, Lupine.

Abundant everywhere, in meadows and on roadsides.

Texas prairies. 
Medicago arabica All. Bur Clover, Spotted Medic.

Similar to the following species but with a dark spot near the center of the leaflet. Occasional here.

Introduced from Europe. Eastern states and California.

Medicago hispida Gaertn. Bur Clover. Toothed Medic.

Abundant everywhere in meadows and roadsides. University campus. The Medics are characterized by their spirally coiled pods.

Introduced from Europe into the eastern states and California.

Medicago sativa L. Alfalfa.

Along railroad tracks and roadsides.

Naturalized from Europe. Extensively cultivated.

Medicago orbicularis.

Roadsides. An old-world species introduced.

Meibomia. (Desmodium Wrightii Gray.) Stiektight. Tick Trefoil. Flood plains.

Texas and New Mexico.

Melilotus alba Desv. White Sweet Clover.

A rather tall, upright, more or less branched weed with rather conspicuous racemes of small white sweet-scented flowers.

Melilotus indica All. Sweet Clover.

Roadsides and waste places. Similar to the preceding except that the flowers are yellow.

Introduced from Europe.

Oxytropis Lambertii Pursh. (Aragallus in the old edition of STmall.) Found occasionally near Austin.

Plains states.

Parosela aurea Britton. (Dalea aurea Nutt.) Prairie Clover. Common on the dry hillsides of the Edwards Plateau.

Plains and prairie states.

Parosela enneandra Brit. (Dalea laxiflora Pursh.)

Dry hillsides of the Edwards Plateau.

Prairie and plains states.

Parosela frutescens Vail. (Dalea frutescens Gray.)

Dry hillsides of the Edwards Plateau.

Texas and New Mexico. 
Petalostemon pubescens Heller. (P. violacens var. pubescens Gray.) Prairie Clover.

Common on the dry hillsides of the Edwards Plateau.

Texas.

Petalostemon purpureus Rydb. (P. violaceus Michx.) Prairie Clover. On the flood plain.

Northern prairies to Texas.

Psoralea cuspidata Pursh.

Dry hills of the Edwards Plateau.

Plains and prairie states.

Psoralea hypogaea Nutt.

Common on the dry hillsides of the Edwards Plateau.

Southern plains states.

Psoralea rhombifolia T. \& G.

Flood plains. Barton Creek.

Sesban macrocarpa Muhl. (Sesbania.)

Flood plains. Barton Creek, near the stream. A tall annual plant with large yellow flowers, and slender pods about a foot long.

Southeastern states to Central America.

Sophora affinis T. \& G.

In the hills of the Edwards Plateau and in roadside thickets in lower ground. Iess common than the following. It can easily be distinguished from the mountain laurel by its lavender flowers, thinner leaves and smaller pods. The pods, constricted between their sperical seeds suggest a string of black beads.

Texas to Arkansas.

Sophora secunidflora DC. Mountain Laural. Coxal Bean.

Very abundant on the hillsides of the Edwards Plateau. An evergreen shrub well known by its large clusters of purple heavy-scented flowers. Its large red seeds are said to be poisonous.

Arkansas to Texas.

Trifolium carolinianum Michx. Clover.

Abundant in waste places and roadsides and open woods.

Southeastern states.

Vicia Leavenworthii T. \& G. Vetch.

Dry ground, meadows and roadsides. Abundant on the campus.

Arkansas to Texas. 


\section{GERANIALES}

\section{GERANIACEAE Genanium Family}

Erodium cicutarium L'Her. Pin Clover. Alfilaria.

Waste ground and open woods.

Introduced from Europe and widespread in Eastern North America.

Erodium texanum A. Gray. Wild Geranium. Stork's Bill.

Very abundant in waste places, roadsides and barren, dry hillsides, carpeting the ground in many places.

Texas to California.

Geranium texanum Heller. Wild Geranium. Crane's Bill.

Abundant in woods and ravines.

Southern Texas. Very closely related to G. caroliniana of the Atlantic and Gulf States.

\section{LINACEAE Flax Family}

Cathartolinum multicaule Hook. Flax.

Common in dry open ground.

Texas plains and prairies.

Cathartolinum rigidum Pursh. Flax.

Dry soil.

Prairie and plains states to Mexico.

Cathartolinum mpestre Engelm. Flax.

Dry soil.

Texas and Mexico. Plains and prairies.

\section{OXALIDACEAE Wood-Sorrel Family}

Ionoxalis Drummondii Rose (I. vespertitionis in the old edition of Small). (Oxalis vespertilionis T. \& G.) Violet Wood Sorrel.

It differs from Xanthoxalis in its large violet flowers and large, deeply lobed leaflets. Ravines or hillsides, rich or barren soil.

Texas to Arizona.

Xanthoxalis corniculata Small. (Oxalis corniculata L.) Yellow Wood Sorrel. Sour Grass.

Very common in waste and cultivated ground, lawns and roadsides. Well known by its trifoliate leaves and acid juice.

Southeastern states. 
Xanthoxalis stricta Small. (Oxalis stricta L.)

Yellow Wood Sorrel. Sour Grass.

University campus, etc.

Widesspread in eastern and central North America.

Xanthoxalis. (Oxalis Wrightii Gray.) Wood Sorrel. Sour Grass. University campus, etc.

West Texas.

\section{ZYGOPHYLLACEAE Caltrop Family}

Kallstroemia intermedia Vail. Caltrop.

Dry waste ground. Abundant on the campus. A prostrate plant with yellow flowers and legume-like compound leaves.

Southern plains and prairie states and Mexico.

Tribulus terestris L. Caltrop. Bur Nut.

Along railroad tracks. Its angled, spiny fruit makes it a very troublesome weed wherever abundant. Similar to Kallstroemia except in fruit.

Introduced into America and now widespread.

\section{RUTACEAE Rue Family}

Fagara Clava-Herculis Small. (Xanthoxylum Clava-Herculis L.) Prickly Ash. Tootache Tree.

Banks of Onion Creek and similar situations. Characterized by its tuberculate, thorny trunk.

Southeastern states.

Fagara fruticosa Small. (Xanthoxylum carolinianum var. fruticosum A. Gray.) Prickly Ash.

A thorny shrub abundant on hillsides, and easily recognized by its glossy compound leaves and strong odor.

Arkansas and Texas.

Ptelea trifoliata L. Hop Tree. Skunk Bush.

One of our most abundant shrubs in ravines and valleys. Easily recognized by its peculiar odor and its round, flat fruits and trifoliate leaves.

Eastern North America.

Thamnosma texana Torr.

Abundant on barren, rocky slopes of the Edwards Plateau. A low partly shrubby plant with small strong scented leaves and two-lobed fruits.

Texas to Mexico. 


\section{SIMARUBACEAE Quassia Family}

Ailanthus glandulosus Desf. Tree-of-Heaven.

Found occasionally growing wild in moist valleys. A common shade tree.

Native of China. Commonly cultivated and often growing wild in eastern United States and Canada.

\section{MELIACEAE Mahogany Family}

Melia Azedarach L. Chinaberry. China Tree.

Growing wild in the valleys. A common shade tree.

Naturalized from Asia in the southern states.

\section{POLYGALALES}

\section{POLYGALACEAE Milkwort Family}

Polygala alba Nutt. Milkwort.

Dry ground.

Central states and Mexico.

Polygala Lindheimeri A. Gray. Milkwort.

Dry hillsides of the Edwards Plateau.

Texas.

\section{EUPHORBIALES}

\section{EUPHORBIACEAE Spurge Family}

Acalypha gracilens var. monococcus Eng.

Eastern states.

Acalypha Lindheimeri Muell. Arg. Three-seeded Mercury.

Very common in waste places.

Texas to Arizona and in Mexico.

Acalypha ostryaefolia Rydb. Three-seeded Mercury.

In moist ground in valleys. An herb which resembles a nettle in appearance but is unarmed.

Southeastern United States and in Mexico.

Acalypha radians Torr.

In dry soil.

Texas and Mexico. 
Bernardia myricaefolia S. Wats.

A common shrub on the river bluffs and ravine sides of the Edwards Plateau. It is irregularly branched and has small thick leaves with toothed or crisped edges.

Texas and New Mexico.

Chamaesyce Fendleri Small. (Euphorbia F'endleri T. \& G.) Spurge.

Dry ground. Mt. Barker.

Southern plains and prairie states and in Mexico.

Chamaesyce maculata Small. (Euphorbia maculata L.) Spotted Spurge.

Roadsides, etc.

Almost throughout North America.

Chamaesyce nutans Small.

Roadsides and waste places.

Widespread in eastern and central United States.

Chamaesyce Nuttallii Small. (Euphorbia petaloidea var. Nuttallii Engelm.) Spurge.

Roadsides and waste places.

South-central states and Mexico.

Chamaesyce prostrata Small. (Euphorbia prostrata Ait.) Prostrate Spurge.

Abundant on roadsides and in waste places. Similar to the following species, but with leaves slightly larger and toothed at the apex. The plant is a darker green than the carpet weeds and clings less closely to the ground.

Gulf states and Mexico.

Chamaesyce serpens Small. Carpet Weed.

Roadsides and waste ground. A small-leaved prostrate plant, forming dense mats over the ground.

Prairie states and Mexico.

Chamaesyce villifera Small. (Euphorbia villifera Scheele.)

Ravines of Edwards Plateau.

Texas.

Cnidoscolus stimulosus A. Gray. (Jatropha stimulosa Michx.) Bull Nettle. Spurge Nettle.

Fields and roadsides. Well known for its beautiful white flowers and its stinging hairs. The sting is much worse than that of the true nettle.

Southeastern states. 
Croton fruticulosus Engelm.

Edwards Plateau.

Texas, New Mexico and Mexico.

Croton monanthogynus Michx.

Abundant in waste places.

Prairie and Gulf states to Mexico.

Croton texensis (Muell.) Arg.

Abundant in waste places, roadsides, etc. The Crotons can be easily recognized by the peculiar odor of their leaves when crushed. Plains and prairie states.

Dichrophyllum bicolor Kl. \& Garcke. (Euphorbia bicolor Engelm.) Snow-on-the-mountain.

Low ground, pastures and roadsides. A tall herb with the leaflike bracts of its flower clusters white-margined.

Southern-central states.

Dichrophyllum marginatum Kl. \& Garcke. (Euphorbia marginata Pursh.) Snow-on-the-mountain.

Roadsides, etc. Similar to the preceding, but smaller.

Central states.

Ditaxis humilis Pax. (Argythaminia humilis Muell.)

Dry ground and waste places.

South-central states.

Ditaxis mercurialina Coulter. (Argythamnia mercurialina Nutt.)

Dry ravines. Abundant in the Edwards Plateau region.

South-central states.

Phyllanthus polygonoides Nutt.

Abundant on the campus.

Dry hillsides, particularly of the Edwards Plateau.

Texas.

Poinsettia dentata Small. (Euphorbia dentata Michx.) Toothed Spurge.

Poinsettia havanensis Small. (Euphorbia heterophylla var. graminifolia Englem.)

Found along Shoal Creek and Barton Creek. Not common.

From Florida to Texas, and in tropical America. 
Poinsettia heterophylla Small. (Euphorbia heterophylla L.) Pointed Leaf.

Waste places.

Central and southern states. Tropical America.

Ricinus communis L. Castor Bean.

Occasional in ravines, etc. Escaped from cultivation.

Tropics, sub-tropics.

Thought to have originated in Africa or India.

Stillingia linearifolia Kl. \& Garcke. (S. angustifolia Engelm.) Queen's Delight.

Common on dry hillsides.

Texas, New Mexico, and Mexico.

Tithymalus arkansanus Kl. \& Garcke. (Euphorbia dictyosperma F. \& M.) Spurge.

Plains and prairie states to Mexico.

Tithymalus commutatus Kl. \& Garcke. (Euphorbia commutata Engelm.) Spurge.

Ravines and moist banks. Abundant along Barton Creek.

Eastern states.

Tithymalus longicuris Small. (Euphorbia Longicuris Scheele.) Spurge.

Open, dry ground. Abundant on the campus.

Southern prairie states.

Tithymalus Missouriensis Small. (Euphorbia arkansana var. Missouriensis Norton.) Spurge.

Open ground.

Plains and prairie states.

Tithymalus Roemerianus Small. (Euphorbia Roemeriana Scheele.) Spurge.

Southern Texas.

Tragia nepetaefolia Cav.

Dry ground.

Southern central states and Mexico.

Tragie ramosa Torr.

Abundant in dry open ground. University campus.

Sounthern plains and prairie states. 


\section{CALLITRICHACEAE Water Starwort Family}

Callitriche heteraphylla Pursh. Water Starwort.

Pools in small streams. A slender plant with small opposite leaves and stems partly or entirely submerged.

Widespread in eastern and central North America.

\section{SAPINDALES}

\section{SPONDIACEAE (ANACARDIACEAE) Sumac Family}

Rhus radicans $\mathrm{L}$. Poison Ivy.

Abundant in moist ravines. Shoal Creek.

A very poisonous vine, climbing by roots, and with 3 -foliate leaves. Widespread in eastern and central North America.

Rhus Toxicodendron L. Poison Oak.

Poisonous. Very similar to the preceding but an upright shrub, not climbing.

Southeastern states.

Schmaltzia lanceolata Small. (Rhus copallina var. lanceolata A. Gray.) Sumac.

Abundant on the dry hillsides of the Edwards Plateau.

A tall shrub pinnately compound leaves.

Texas.

Schmaltzia trilobata Small. (Rhus canadensis var. trilobata Gray.)

Skunk Bush. Ill-scented Sumac.

Abundant in ravines and on hillsides. Easily recognized by its three leaflets and its disagreeable odor.

Central and western states.

Schmaltzia virens Small. (Rhus virens Lindh.) Evergreen Sumac.

An evergreen shrub with pinnately compound leaves. Abundant on the dry hillsides of the Edwards Plateau.

Texas, New Mexico, and Northern Mexico.

\section{AQUIFOLIACEAE Holly Family}

Ilex decidua Watt. Deciduous Holly. Possum Haw. Bear-berry. Very common in ravines and well known by its abundant scarlet berries. A shrub or small tree.

Ilex vomitoria Ait. Yaupon.

A beautiful evergreen shrub with scarlet berries common in the moist ravines of the Edwards Plateau.

Southeastern states. 


\section{AESCULACEAE (HIPPOCASTANACEAE) Buckeye Family}

Aesculus Pavia L. Red Buckeye.

Very common in ravines and on the lower slopes of the Edwards Plateau. A small tree, with beautiful clusters of reddish blossoms in the spring. Recognized by its large palmately compound leaves.

Southeastern States.

\section{ACERACEAE Maple Family}

Rulac texana Small. Box elder. Ash-leaved Maple.

Flood plain of the Colorado. A common shade tree in Austin. Very similar to Rulac Negundo, but with pubescent twigs.

Central North America from Canada to Mexico.

\section{SAPINDACEAE Soapberry Family}

Cardiospermum Halicacabum L. Balloon Vine.

Flood plains of Barton Creek and Waller Creek. A vine cultivated and named for its balloon-like pods.

The southeastern states. Tropical America.

Sapindus Drummondii. Soapberry. Wild China Tree.

Ravines and hillsides. A common shade tree in Austin. Easily identified by its pinnately compound leaves and large yellow berrylike fruits.

Southern central states and Mexico.

Ungnadia speciosa Endl. Mexican Buckeye. Spanish Buckeye.

Texas Buckeye.

Abundant in ravines and on moist rocky hillsides. Very common in the ravines of the Edwards Plateau. A shrub well known by its three-lobed pods in which the dry seeds rattle when mature.

Texas, New Mexico, Mexico.

\section{RHAMNALES}

\section{FRANGULACEAE (RHAMNACEAE) Buckthorn Family}

Berchemia scandens Trelease. Rattan. Supple-Jack.

A climbing (or twining) shrub with long smooth supple branches. Abundant in ravines and on moist bluffs of the Colorado.

Southeastern states.

Ceanothus ovatus Desf. Red Root.

A low shrub commonly found on the bluffs and in the ravines of the Edwards Plateau.

Southeastern States. 
Colubrina texensis A. Gray.

A common shrub of the dry hillsides and hilltops of the Edwards Plateau, growing often in dense thickets.

Texas and northern Mexico.

Condalia obovata Hook.

One of the most abundant shrubs of the dry hillsides of the Edwards Plateau. Thorny and often nearly leafless in the dry season.

Central Texas to northern Mexico.

Rhamnus caroliniana Walt. Buckthorn. Indian Cherry.

Common in the ravines of the Edwards Plateau. A shrub or small tree with firm glossy leaves and black berries.

Southeastern states.

Ziziphus obtusifolia A. Gray. (Condalia obtusifolia.) Loti-bush. Te" as Buckthorn.

On bluffs and rocky hillsides. A thorny shrub somewhat similar to Condalia.

Ziziphus vulgaris Lam. Jujube.

Roadsides in Austin. Probably planted or escaped from cultivation.

Naturalized in the Gulf states, from Europe and Asia.

\section{VITACEAE Grape Family}

Ampelopsis arborea Rusby. Pepper-vine.

Moist ground in valleys. Shoal Creek. A climbing vine.

Southeastern states, West Indies, Mexico.

Cissus incisa Desmoul.

A climbing vine with crisp, succulent, 3 -folicte leaves, and black berries. The foliage when crushed has a very disagreeable odor.

Southern states.

Parthenocissus quinquefolia Planch. (Ampelopsis Michx.) Virginia Creeper. Woodbine. Five-leaved Ivy.

A climbing vine often mistaken for poison ivy, but easily distinguished from it by its five leaflets, and its tendrils clinging by disks.

Widespread in the eastern United States and Canada.

Vitis candicans Engelm. Mustang Grape.

Ravines. The leaves are white-woolly beneath. The grapes ripen in July and are used by many people for jelly.

Texas. 
Vitis cinerea Engelm. Downy Grape.

Ravines and the river bluffs. The leaves are soft-hairy beneath, and the grapes ripen in the fall.

Central and southern states and in Mexico.

Vitis cordifolia Lam. Frost Grape. Chicken Grape.

Ravines. The leaves are smooth or slightly soft-hairy beneath. The grapes are small and ripen in the fall.

Eastern and central States.

\section{MALVALES}

\section{MALVACEAE Mallow Family}

Abutilon incanum Sweet. Indian Mallow.

Very common in dry ground. The Abutilons are characterized by their velvety leaves.

Arkansas to Texas and Mexico.

Abutilon texense T. \& G. Indian Mallow.

Dry Ground.

Texas and New Mexico.

Abutilon Wrightii A. Gray. Indian Mallow.

Dry ground.

Texas to Mexico.

Callirrhoe digitata Nutt. Poppy Mallow. Wine Cup.

Very common in fields and open woods. A perennial with long slender spreading stems and large purple-red flowers.

Southern central states.

Callirrhoe involucrata A. Gray. Poppy Mallow. Wine Cup.

Similar to the preceding.

Gulf states.

Callirrhoe papaver A. Gray. Poppy Mallow.

Similar to the preciding, but less common.

Gulf states.

Malva borealis Wallm. (Not given in Small.)

Abundant in a few places in fields and roadsides.

A plant of the Old World, naturalized in Texas.

Malva rotundifolia L. Mallow, Cheeses.

Roadsides and waste places. Not common here.

Widespread in North America. Native of Europe and Asia. 
Malvastrum americanum Torr.

Roadsides and waste places.

Gulf states. Tropical America.

Malvaviscus Drummondii T. \& G. "Mexican Apple."

Abundant in moist woods. A rather coarse herb with red flowers and large red berry-like fruits.

Gulf states and Mexico.

Modiola caroliniana G. Don.

In the flood plains of Bee Creek and Bull Creek.

Gulf States, Central and South America.

Pavonia lasiopetala Scheele.

Common in woods and rocky bluffs. A shrubby plant with handsome pink flowers.

Texas and Mexico.

Sida filiformis Moric.

Abundant on roadsides, the campus, etc.

Texas to Mexico.

Sida diffusa HBK.

Very similar to the preceding and in similar situations.

Texas, New Mexico and Mexico.

Sida fifilipes A. Gray.

Rare here.

Western Texas.

Sida hastata St. Hil. (S. physocalyx A. Gray.)

Roadsides, etc., in deep soil.

Texas and New Mexico.

Sida spinosa L.

Waste places and roadsides.

Widespread in the tropics and eastern United States.

Wissadula holosericea Garcke. (Abutilon holosericeum Scheele.)

Texas and Mexico.

\section{HYPERICALES}

\section{HYPERICACEAE St. John's-Wort Family}

Ascyrum hypericoides L. St. Andrew's Cross.

Found near the dam. Rare here.

Introduced in the southeastern states from tropical America. 


\section{CISTACEAE Rock-rose Family}

Helianthemum rosmarinifolium Pursh. Rock-rose. Frost Weed. Postoak woods.

Southeastern states.

Lechea tenuifolia Michx. Pin-weed.

Postoak woods.

Eastern states.

\section{VIOLACEAE Violet Family}

Calceolaria verticillata Kuntze (Ionidium polygalaefolium Vent.) Nodding Violet. Green Violet.

Roadsides, University campus, etc.

Southern plains and prairie states.

Viola missouriensis Green. Blue Violet.

In moist, rich soil in ravines. Barton Creek, Onion Creek.

Not abundant here.

Southern central states.

\section{OPUNTIALES}

\section{OPUNTIACEAE (CACTACEAE) Cactus Family}

Cactus missouriensis Kuntze (Mammillaria missouriensis Sweet.) Nipple Cactus.

Dry soil. Not common here. The plant is nearly spherical, one or two inches high and covered with cylindrical tubercles.

Plains and prairie states.

Echinocatus texensis Hoepf. Devil's Pin-cushion.

Very common in dry open ground on hillsides and uplands. The large round ridged apex of the plant, covered with stout pink thorns, usually just appears above the surface of the ground.

Southern Texas and Mexico.

Echinocactus setispinus Engelm.

Dry hillsides. The nearly globular stems are from two to four and a half inches in diameter, and with long slender spines.

Texas and Mexico.

Echinocereus caespitosus Engelm. \& Gray.

Dry hillsides. One of our most abundant species. The short cylindrical stems are usually clustered. The clustered spines are short and spreading, giving a peculiar scale-like appearance.

Southern plains states to Mexico. 
Opuntia arborescens Eng.

Found in a few places here along roadsides.

Southern plains states to Mexico. Common in West Texas.

Opuntia Lindheimeri Engelm. (O. Engelmanni Salm.) Prickly Pear. The most common cactus. Abundant on roadsides and in dry and waste places.

Texas to California and in Mexico.

Opuntia leptocaulis P. DC. Tasajillo.

Common on roadsides and in waste places and thickets. A woody shrub with slender cylindrical branches and loosely sheathed spines. This plant is one which it it well to avoid, as the spines are hard to remove from the flesh and often cause troublesome sores.

Texas to Arizona and Mexico.

Opuntia macrorhiza Engelm. Prickly Pear.

Similar to $O$. Lindheimeri, but smaller and usually prostrate.

Southern-central states.

\section{THYMELEALES}

\section{LAURACEAE Laurel Family}

Benzoin aestivale Nees. (B. Benzoin in the old edition.) Spice Bush. In moist soil in deep ravines. Bee Creek. Not common. A shrub recognized easily by the spicy fragrance of its leaves.

Eastern states.

\section{MYRTALES}

\section{LYTHRACEAE Loosestrife Family}

Ammannia coccinea Rottb.

Waller Creek.

Central and Gulf states to Central and South America.

Lythrum lanceolatum Ell. Loosestrife.

Moist ground. Not common here.

Southeastern states.

\section{EPILOBIACEAE (ONAGRACEAE) Evening Primrose Family}

Gaura brachycarpa Small.

River flood plain.

Southern Texas. 
Gaura Drummondii T. \& G.

Fields and roadsides, University campus.

Texas to Mexico.

Gaura parviflora Dougl. Wild Honeysuckle.

Common in fields and roadsides.

Plains and prairie states.

Gaura sinuata Nutt. Wild Honeysuckle.

Fields and roadsides. University campus.

Southern plains and prairie states and in Mexico.

Gaura suffulta Engelm. Wild Honeysuckie. Bee Blossom.

Very common in fields, waste places and roadsides. Abundant on the University campus.

Oklahoma, Texas and Mexico.

Hartmannia speciosa Small. Primrose.

Abundant everywhere in fields, roadsides and waste places. Our most common primrose. Locally called "buttercup" although the flowers are pink.

Southern plains and prairie states to northern Mexico.

Isnardia natans Small. (Ludwigia natans Ell.) Marsh Purslane.

In muddy ground along Shoal Creek.

Southeastern states to Mexico.

Jussiaea diffusa Forskl.

In streams and wet ground along streams. Very abundant in Barton Creek. The stems and leaves usually with a reddish tinge. Southern states, tropical America and Asia.

Jussiaea suffruticosa L.

In wet ground along Barton Creek and Waller Creek.

Southeastern states and the tropics.

Lavauxia triloba. Spach. (Oenothera triloba Nutt.) Primrose. Buttercup.

Abundant in fields and roadsides. Ours is a yellow-flowered form and probably should be differently named.

Lavauxia Watsoni Small. (Oenothera triloba var. parviflora S. Wats.) Evening Primrose.

In rich soil. Similar to the preceding but smaller and opening only in the evening. The petals are yellow, but turn reddish when they wither.

Kansas and Nebraska, to Oklahoma. 
Megapterium Missouriense Spach.

Common on dry hillsides of the Edwards Plateau. With very large yellow flowers and winged pods.

Southern plains and prairie states.

Meriolix melanoglottis Rydb. Primrose.

Similar to the following species, but with the inside of the cup and the stigma black. Occasional in dry soil.

Colorado to Texas.

Meriolix serrulata Walp.

Roadsides, etc.

Plains and prairie states.

Meriolix spinulosa Heller. (Oenothera serrulata T. \& G.)

Abundant on roadsides and hillsides and along railroad tracks. Very similar to the preceding but with larger flowers. The flowers of both are yellow and the leaves slender and toothed.

Southern plains and prairie states.

Oenothera laciniata Hill. (Oenothera sinuata L.) Evening Primrose.

Dry ground, roadsides and along railroads. Flowers yellow.

Eastern and central states, Mexico and South America.

Oenothera laciniata grandis Britton. (O. sinurta var. grandiflora Heller.) Evening Primrose.

Common on the river flood plain. Similar to the preceding but with large flowers.

Southern-central states.

Onagra Jamesii Small. (Oenothera Jamesii T. \& G.) Evening Primrose.

On the bank of Barton Creek. Very large yellow flower.

Southern plains states.

\section{GUNNERACEAE (HALORAGIDACEAE) Water Milfoil Family}

Myriophyllum heterophyllum Michx. Water Milfoil.

Barton Creek. Growing submerged similar to Ceratophyllum, but less branched, and with softer, pinnately divided leaves.

Widely distributed in eastern North America.

Myriophyllum proserpinacoides Gill. (Not in Small.) Parrots Feather.

Found in Shoal Creek. Escaped from cultivation.

Native of Chile and widely cultivated in acquaria. 


\section{AMMIALES \\ NYSSACEAE (CORNACEAE) Dogwood Family}

Garrya Lindheimeri (Torr.). (G. ovata var. Lindheimeri Coult. and Evans.)

A common shrub on the bluffs in ravines of the Edwards Plateau. Texas.

Svida asperifolia Small. (Cornus asperifolia Michx.) Dogwood.

On the river bank, under the bluffs. A shrub.

Central and southern states.

\section{AMMIACEAE (UMBELLIFERAE) Carrot Family}

Ammi majus L.

Found in the river flood plain.

Native of Europe. Naturalized in southwest Texas.

Ammoselinum Butleri Coult. \& Rose. Sand Parsley.

In low muddy ground.

Central states.

Apium ammi Urban. Marsh Parsley.

Common on roadsides, etc.

Southeastern states and the tropics.

Berula erecta (Huds). Coville.

In swamps and streams.

Texas and Mexico to California.

Bowlesia septentrionalis Coult. \& Rose. (B. lobata Ruiz \& Pavon.) Very common in moist rich ground, in yards, river banks, etc. A low delicate plant with round, lobed leaves and small white flowers. Texas to California.

Chaerophyllum Teinturieri Hook. Chervil.

Very common in woods, and on roadsides in good soil.

Southeastern states.

Daucus Carota L. Wild Carrot.

Fields, roadsides and waste places. Summer.

Naturalized from Europe and Asia and widespread in North America. 
Daucus pusillus Michx. Wild Carrot. Stick-tight. Queen Anne's Lace.

Fields, roadsides, and waste places. Very similar to the preceding but blooming in the spring.

Southern and western states.

Eryngium Leavenworthii T. \& G. Button Snake Root.

Dry barren ground. A rigid plant with spiny leaves and flowers in dense, spiny heads.

Kansas to Texas.

Hydrocotyle umbellata L. Marsh Pennywort. Water Pennywort. Moneywort.

Very abundant along the edges of streams. A creeping plant with round glossy leaves and clusters of small white flowers.

Southeastern states.

Hydrocotyle verticillata Thumb.

Similar to the preceding.

Eastern and central states.

Lomatium daucifolium Coult. \& Rose.

Not common here.

Southern prairie states.

Sanicula canadensis L. Snake-root.

Moist ground, Sidon Harris Park.

Eastern states.

Sanicula gregaria Bicknell. Black Snake-root.

In rich soil in shaded ravines. Onion Creek. Rare here.

Eastern and central states.

Spermolepis echinatus Heller.

Roadsides, etc.

Southern states.

Torilis nodosa Gaertn. Hedge Parsley.

Very common in waste ground and on roadsides. University campus. The outer fruits of a cluster are covered with barbed spines, the inner not.

Naturalized from Europe and Asia and widely distributed on this continent. 


\section{ERICALES \\ ERICACEAE Heath Family}

Arbutus Xalapensis. HBK. Madrona.

A small tree found in places in the ravines of the Edwards Plateau. The bark peels off in thin reddish sheets leaving a smooth fleshcolored surface.

Abundant in the mountains of West Texas.

\section{PRIMULALES}

\section{PRIMULACEAE Primrose Family}

Anagallis arvensis $\mathrm{L}$.

Roadside. Rare here. Ours is the blue form, A. arvensis caerulea Ledeb.

Naturalized from Europe and widespread in North America.

Dodecatheon Meadia L. Shooting Star. American Cowslip.

Abundant in the flood plain and banks of Bull Creek.

Eastern and central states.

Samolus cuneatus Small. Water Pimpernel. Brokweed.

Wet rocks or mud, along the river, Barton Creek, etc.

Texas.

Samolus floribundus H.B.K. (S. valerandi var. Americancus Gray.)

Water Pimpernel. Brookweed.

Barton Springs, etc.

Widespread in North America.

\section{EBENALES}

\section{EBENACEAE Ebony Family}

Brayondendron texanus Small. (Diospyros texana Scheele.) Mexican Persimmon.

Very common in valleys and rocky slopes. A bushy shrub or small tree with many slender twigs and with small thick leaves, wooly below. The fruit is black.

Texas and Mexico.

\section{SAPOTACEAE Sapodilla Family}

Bumelia lanuginosa Pers. Gum Elastic. Shittimwood.

A shrub or small tree. Very abundant on dry hillsides on roadsides, woods and waste ground. University campus.

Southern prairie and Gulf states. 


\section{STYRACACEAE Storax Family}

Styrax platanifolia Engelm.

In moist ravines of the Edwards Plateau. A beautiful shrub wit? thin, glossy, angled leaves, and clusters of white, bell-shaped flowers.

Texas.

\section{OLEALES}

\section{OLEACEAE Olive Family}

Adelia pubescens Kuntze. (Foresteria pubesccens Nutt.)

One of the most common shrubs in our ravines. Easily recognized by its small oval leaves and opposite branches. It is the first shrub to bloom in the spring, the blossoms appearing before the leaves. The yellow male flowers, though small, are very abundant, and conspicuous by their fragrance and the swarms of insects which they attract. The flowers of the female bushes are greenish and inconspicuous.

Oklahoma to Texas and New Mexico.

Fraxinus lanceolata Borck. (F. viridis Michx.) Green Ash. Swamp Ash.

Ravine near Montopolis Bridge.

Widespread in Eastern United States and Canada.

Fraxinus texensis Sarg. (F. americana var. texensis Gray.) Texas Ash.

Hillsides in ravines. Shoal Creek valley, etc.

Texas.

Menodora heteraphylla Moric.

Dry soil, open ground and in open woods. Campus.

Texas and Mexico.

\section{GENTIANALES}

\section{SPIGELIACEAE (LOGANIACEAE) Logania Family}

\section{Buddleia ramosa Torr.}

Abundant in the crevices and ledges of rock bluffs. A low, muchbranched shrub with white flowers in small globular clusters.

Western and southern Texas.

Coleostylis Lindheimeri Small. (Spigelia Lindheimeri Gray.)

Occasional in dry ground.

Texas and Mexico. 
Cynoctonum Mitreola Britton. (Mitreola petiolata T. \& G.) Mitrewort.

Moist soil; creek banks.

Southeastern states, West Indies, Mexico.

Polypremum procumbens $\mathrm{L}$.

In the postoak woods.

Southeastern states, West Indies, Mexico.

\section{GENTIANACEAE Gentian Family}

Erythraea Beyrichii T. \& G. Mountain Pink. Eentaury.

Dry, rocky hillsides and rock bluffs of the Edwards Plateau. A stiff, much-branched herb with abundant bright pink flowers which will dry without withering.

Arkansas and Texas.

Erythraea calycosa Buckl. Centaury.

Rare here.

Southern central states.

Eustoma Russellianum Grisib. Blue Gentian.

Abundant in prairie land and along railroad track, but not common near Austin. The large, rather stiff blue flowers are very showy.

Southern plains and prairie states.

Sabbatia campestris Nutt. Texas Star.

Found occasionally in the postoak woods. The flowers are similar to those of Erythraea Beyrichii, but larger and fewer; and with a conspicuous yellow center.

Southern prairie states. Very abundant in parts of eastern and southern Texas.

\section{ASCLEPIADALES}

\section{APOCYNACEAE Dogbane Family}

Amsonia texana Heller. (A. Giliata var. texana.) Texas Star. Hillsides of the Edwards Plateau.

Texas.

\section{ASCLEPIADACEAE Milkweed Family}

Asclepias Lindheimeri Engelm. Milkweed.

Dry uplands.

Texas, New Mexico and Mexico. 
Seed Plants, Ferns, Fern Allies of the Austin Region 61

Asclepias texana Heller. Milkweed.

Bee Creek.

Southern Texas.

Asclepias verticillata L. Milkweed.

Occasional here.

Eastern and central states and Canada.

Asclepiodora decumbens A. Gray. Milkweed. Antelope Horns.

Very abundant in dry, open ground.

Southern plains states and Mexico.

Asclepiodora viridis A. Gray. Antelope Horns.

Less common than the preceding species and smaller.

Southern states.

Gonobolus laevis Michx. (Enslenia albida Nutt.) Climbing Milkweed.

Valleys and moist bluffs. A climbing vine with leaves similar to a morning glory vine.

Southern states.

Metastelma barbigerum Scheele.

Hillsides of the Edwards Plateau. A slender, twining vine with small glossy leaves and small white flowers.

Texas.

Philibertella crispa Vail. (Philibertia undulata Gray.)

Found occasionally on the hills of the Edwards Plateau.

West Texas and New Mexico.

Vincetoxicum biflorum Heller. (Gonobolus biflorus Nutt.) Anglepod.

Common on dry uplands.

Arkansas and Texas.

Vincetoxicum reticulatum Heller. (Gonobolus reticulatus Englem.) Angle-pod.

In rich soil in woods and rocky hillsides. An ill-scented climbing vine, with small mottled green flowers.

Texas to Arizona and in Mexico.

\section{POLEMONIALES}

\section{DICHONDRACEAE Dichondra Family}

Dichondra carolinense Michx.

In rich soil in dense woods, lawns, ets. Abundant. A creeping plant with small round, or reniform leaves.

Southeastern states. 


\section{CONVOLVULACEAE Morning Glory Family}

Breweria Pickeringii A. Gray.

Not abundant here.

Southeastern States.

Convolvulus hermannioides A. Gray. Bindweed.

Abundant in dry, open ground. University campus, etc.

Texas plains and prairies.

Convolvulus incanus Vahl. Bindweed.

Common in open, dry ground.

Southern plains states.

Evolvulus pilosus Nutt. (E. argentus Pursh.)

Dry hills of the Edwards Plateau.

Plains states to Mexico.

Evolvulus sericeus Sw.

Open ground. University campus.

Gulf states to Arizona and in tropical America.

Ipomoea trifida G. Den. var. Torreyana Gray. Morning Glory.

Abundant in flood plains and roadsides. Our common pink morning glory.

Texas, Mexico and tropical America.

\section{CUSCUTACEAE Dodder Family. (Under CONVOLVULACEAE)}

Cuscuta arvensis Beyrich. Dodder. Love Vine.

Abundant along the shores of Barton Creek. A slender parasitic vine with yellow stems, twining around weeds and often forming dense mats.

Widespread in North America.

Cuscuta Gronovii Willd. Dodder, Love Vine.

Along the shore of Barton Creek.

Widespread in Eastern North America.

\section{HYDROLEACEAE Water-leaf Family}

Marilaunidium Jamaicense Kuntze. (Nama Jamaicense L.)

Abundant in rich soil. Flood plains, roadsides, etc.

Gulf states, West Indies, and Mexico.

Marilaunidium hispidum Kuntze. (Nama hispida Gray.)

Abundant on the river flood plain.

Texas to Arizona. 
Nemophila phacelioides Nutt.

Abundant in moist rich soil, valleys, woods and roadsides. One of our conspicuous spring flowers, with rather rough, divided leaves and large delicate blue blossoms.

Arkansas and Texas.

Phacelia congesta Hook.

Abundant in moist, rich soil and in dryer places. Most common in woods. One of our conspicuous spring flowers. With thin, softhairy, divided leaves, and small blue flowers in elongated, coiled clusters.

Texas.

Phacelia patuliflora Gray.

River flood plain and along railroad tracks.

\section{POLEMONIACEAE Phlox Family}

Gilia incisa Benth.

Abundant in woods. Mt. Bonnell, etc.

Texas and Mexico.

Gilia rigidula Benth.

One of the most beautiful and striking flowers of our dry, rocky hillsides. A rigid, much-branched little plant with needle-like leaves and flowers of a very bright deep blue.

Texas and Mexico.

Gilia mubra Heller. Standing Cypress.

Rare here, but abundant along railroad tracks in many places near Austin. A tall slender plant with finely divided leaves and stout spikes of large elongated red flowers.

Southeastern states.

Phlox Drummondii Hook.

Abundant in open ground. River flood plain.

Texas.

Phlox Romeriana Scheele.

Abundant in open ground and woods. Uplands of the Edwards Plateau and the river flood plain. With large pink flowers. Our most beautiful Phlox.

Texas prairies.

Phlox tenuis E. Nelson.

Eastern and southern Texas. 


\section{SOLANACEAE Potato Family. Nightshade Family}

Bouchetia anomala Brit \& Rusby.

Common on roadsides and in waste places, University campus, etc. Texas and tropical America.

Capsicum baccatum L. Bird Pepper. Chiltipin.

Canyons of the Colorado River, Waller Creek, etc.

Gulf states and the tropics.

Chamaesaracha conioides Britton.

Occasional on dry slopes of the Edwards Plateau.

Southern plains states.

Chamaesaracha Coronopus A. Gray.

Abundant on dry hillsides and in waste ground.

Southern plains states.

Datura meteloides DC. Jimson Weed. Stramonium. Thorn Apple. Sandbanks along the river.

Texas to California and in Mexico.

Datura Stramonium L. Jimson Weed. Stramonium.

Sandbanks along the river.

Naturalized from the tropics and widespread in eastern North America.

Nicotiana repanda Willd. Wild Tobacco.

Low ground and hillsides. Very common. A tall, coarse-leaved plant with white blossoms.

Texas and Mexico.

Nicotiana trigonophylla Dunal. Wild Tobacco.

Low ground and hillsides. Less common than the preceding species and smaller.

Texas to California and in Mexico.

Petunia parviflora Juss.

On the river bank. A low, much-branched plant with small, purple flowers.

Gulf' states to California and in the tropics.

Physalis angulata. L. Ground Cherry. Jerusalem Cherry.

Rich ground in valleys.

Southeastern States, Central and South America. 
Physalis heterophylla Nees. Ground Cherry, Jerusalem Cherry.

Rich moist soil.

Eastern states and Canada to Colorado and Texas.

Physalis mollis Nutt. Ground Cherry. Jerusalem Cherry.

Common in rich soil in valleys and on shaded hills.

Southwestern states and in Mexico.

Solanum carolinense L. Horse Nettle.

A somewhat thorny weed, abundant in fields, roadsides and waste places. With large, rough. lcbed leaves. blue flowers, and globular, yellow fruits nearly an inch in diameter.

Eastern and central states.

Solanum eleagnifolium Cav. Blue Nightshade.

One of our most common weeds. Abundant everywhere in fields, roadsides, and waste places. Differing from the preceding in its narrower, whitish leaves and smaller fruits. It is either unarmed or with slender prickles.

Solanum heterodoxum Dunal. (Not named in Small.)

Found on sand banks of the Colorado River. Not common.

A west Texas spcies very similar to S. rostratum.

Solxnum nigrum L. Common nightshade. Black Nightshade.

Common in rich ground in ravines and valleys.

Widely distributed in North America and other countries.

Solan'm mstratum Dunal. Buffalo Bur. Prickly Solanum. Tread Softly.

Abundant in open ground and waste places. One of our most common weeds. The flowers are yellow, the whole plant very thorny and the fruit enclosed in a prickly calyx.

Central states and Mexico.

Solanum Torreyi A. Gray. Torrey's Nightshade.

Similar to $S$. carolinense, but with larger berries.

Southern central states.

Solanum triquetrum Cav. Nightshade.

Common in moist soil in ravines. University campus. A vinelike plant with slender branches, white flowers and bright red berries.

Texas and Mexico.

\section{BORRAGINACEAE Borage Family}

Lithospermum hreviflom Engelm. \& Gray. Collected by E. I. Palmer. 
Lithospernum linearifolium Goldie. Puccoon. Gromwell.

Common in dry ground and stony hillsides. University campus. Widespread in North America, especially in the prairie regions.

Myosotis virginica B. \& P. (M. verna Nutt.) Forget-me-not. Dry ground. Banks of the Colorado River.

Eastern United States and Canada.

Onosmodium Bejariense DC. False Gromwell.

Abundant in dry woods. A herb with rather large, coarse and bristly leaves, and smooth white nut-like fruits.

Texas.

Onosmodium Helleri Small.

In the hills of the Edwards Plateau. Less common than the preceding.

Texas.

\section{EHRETIACEAE Ehretia Family (Under BORRAGINACEAE)}

Ehretia elliptica DC. Anaqua. Sugarberry.

Occasional in valleys and along the Colorado River. A tree easily recognized by its very rough oval leaves.

Texas and Mexico.

Heliotropium tenellum Torr.

In dry ground.

Southern-central states.

\section{VERBENACEAE Verbena Family}

Aloysia ligustrina Small. (Lippia ligustrina Brit.) White-brush.

Common on dry hillsides. A shrub with small leaves and graceful sprays of small fragrant white flowers. It forms dense thickets on barren dry hillsides in many parts of the state. Abundant in West Texas.

Southwestern states and Mexico.

Callicarpa americana L. French Mulberry.

Very common in the moist ravines of the Edwards Plateau. A shrub with coarse, opposite leaves and pink flowers clustered in the axils. Late in the season the plant is made conspicuous by its clusters of small lilac fruits.

Southeastern states. 
Lantana horrida. H. B. K.

Common along roadsides and in dry ground. A low shrub with clusters of orange flowers.

Gulf states to Central America.

Phyla nodiflora Green. (Lippia nodiflora L.)

Common everywhere in dry ground, roadsides, etc. Abundant on the University campus. A prostrate, creeping plant with small whiteish flowers in very dense spherical or short cylindrical heads.

Southeastern states and California. Warmer regions of both the Old and the New World.

Verbena bipinnatifida Nutt. Wild Verbena. Vervain.

Very abundant in open ground. Our common verbena. A perennial plant usually about 15 inches high, with conspicuous dense oblong spikes of bright pink flowers.

Prairie and plains states. From South Dakota to Mexico.

\section{Verbena ciliata Benth.}

Dry ground. A low plant, with branches spreading over the ground. Its flower clusters are similar to those of $V$. bipinnatifida, but smaller.

Southern plains states.

\section{Verbena canescens H.B.K.}

Common in dry soil. University campus. A rather low plant with clustered stems and densely gray hairy foliage.

Texas to Arizona, and Mexico.

\section{Verbena officinalis L. Vervain.}

Very common in fields, roadsides, and waste places. An annual plant one or two feet tall with slender stems and with small flowers in long slender spikes. University campus. Perennial here.

\section{Eastern states.}

\section{Verbena pumila Rydb.}

Common in waste places and dry ground. Very similar to V. ciliata. Oklahoma and Texas.

\section{Vitex Agnus-Castus L.}

Occasional on the river flood plain. A shrub with digitately 5-7 foliate leaves.

Southeastern states. 


\section{LAMIACEAE (LABIATAE) Mint Family}

Brazoria scutellarioides Engelm. \& Gray.

Common in moist ground, ravines, valleys, bluffs and hillsides. One of our most beautiful mints. Its dense, stiff spikes of pink flowers are conspicuously 4-sided.

Texas.

Hedeoma acinoides Scheele. Mock Pennyroyal.

Abundant in ravines, hillsides and uplands of the Edwards Plateau. A small annual, with slender branches and delicate pink flowers: the whole plant with a strong lemon odor.

Arkansas and Texas.

Hedeoma Drummondii Benth. Mock Pennyroyal.

Similar in habit and habitat but less abundant than the preceding. Lemon-scented.

Texas.

Lamium amplexicaule L. Dead Nettle. Henbit.

Very common in lawns and along the roadsides in Austin. Abund ant on the campus. One of the first plants to bloom in the spring.

The flowers in our form are red-purple.

Native of Europe and widespread in eastern North America.

Leonotis nepetaefolia $\mathrm{R}$. Br.

Valley of Onion Creek.

Southeastern states and the tropics.

Marmibium vulgare L. Hoarhound.

Waste places everywhere. One of our most common weeds. Easily recognized by its white woolly stems and dull wrinkled leaves.

Naturalized from Europe and widespread in eastern North America.

Mentha spicata L. Spearmint.

Wet ground near spring. Marshall Goat Ranch.

Eastern North America.

Mentha sp. Peppermint.

Wet ground along Onion Creek, and in wet places in ravines in the Bull Creek region.

Monarda dispersa Small. Horse-mint.

Abundant in fields and roadsides. One of our most common mints. A tall annual plant, very strong scented, and with large globular clusters of flowers in the axils of the upper leaves. Some of the bracts are colored lavender, like the flowers.

Southern plains states to Mexico. 
Monarda lasiodonta Small. Horse-mint.

A species with purple-dotted yellow flowers. Occasional on the river flood plain.

South central states.

Monarda Stanfieldii Small. Horse-mint.

Occasional on the river flood plain. Similar to the preceding.

Indian Territory and Texas.

Physostegia intermedia A. Gray. Dragon Head. Lion's Heart.

Moist ground. Ravines and moist bluffs.

Southeastern States.

Salvia coccinea $L$. Scarlet Sage.

Moist ground. Waller Creek. With scarlet flowers.

Southeastern states to Mexico.

Salvia farinacea Benth. Blue Sage.

Abundant everywhere in rich soil, fields, roadsides and waste places. University campus. Our most common sage. Conspicuous on account of its white felty stems and deep bine flowers.

Texas.

Salvia Roemeriana Scheele. Scarlet Sage.

Abundant in ravines of the Edwards Plateau. With scarlet flowers.

Texas.

Salviastrum texanum Scheele.

Common in dry ground, rocky hillsides. University Campus. One of the most abundant herbaceous plants on the dry slopes of Mt. Bonnell, and Mt. Barker. Conspicuous for its rough-hairy leaves and large blue flowers.

Texas.

Scutellaria Drummondii Benth. Skullcap.

Very common in valleyes and hillsides. The Scutellarias can always be recognized by the peculiar bonnet-shaped calyx, opening by a horizontal slit. The flowers of both our species are blue.

Southern plains states.

Scutellaria resinosa Torr. Skullcap.

A perennial, abundant on the dry hillsides of the Edwards Platrau. One of the most common plants of the upper slopes of Mt. Bonnell and Mt. Barker.

Texas. Southern plains states. 
Stachys agraria Cham. \& Schl. Hedge Nettle. Woundwort.

Common in moist or shaded ground, in valleys and on roadsides. Tevas and Mexico.

Teucrium canadense $\mathrm{L}$.

Bee Creek ravine, Waller Creek. Not common here.

Eastern states.

\section{RHINANTHACEAE (SCROPHULARIACEAE) Figwort Family}

Antirrhinum antirrhiniflorum Small. (A. maurandioides Gray.) Snapdragon.

Abundant on shaded bluffs. Barton Springs. A slender, climbing vine with small leaves and conspicuously irregular blue or purple flowers.

Texas to Arizona and in Mexico. A very common vine in the foothills of the Davis Mountains.

Castilleja Lindheimeri Gray. Painted Cup. Indian Paint Brush.

Dry, rocky hillsides. One of the most conspicuous flowers on the high, barren slopes of Mt. Bonnell and Mt. Barker. The orange, red flowers and similarly colored bracts are very showy.

Texas.

Conobea multifida Benth.

Abundant in the dry bed and on the banks of Shoal Creek.

Central states.

Gerardia heterophylla Nutt.

Dry ground. Along railroad tracks.

Southern prairie states.

Gerardia strictiflora Benth.

Dry grounds. Along railroad tracks.

Southern prairie states.

Leucophyllum texanum Benth.

On dry rocky ledges. Barton Creek. A striking and beautiful shrub with white-woolly foliage and pink bellshaped flowers.

Texas and Mexico.

Linaria texana Scheele. Toad flax.

Very common in woods, fields and roadsides. A slender plant with delicate, long-spurred blue flowers.

Widespread. Chiefly in the southern states. 
Mecardonia procumbens Small. (Herpestris chamaedryoides H.B.K.) Abundant in moist ground along Barton Creek and Shoal Creek. Florida and Texas. American tropics.

Mimulus Jamesii Torr \& Gray. (M. Geyeri Torr.) Monkey-flower. In the mud along small streams in ravines. Mt. Bonnell.

Widespread in eastern North America. Common in the Rocky Mountains.

\section{Monniera Monniera Britton. (Hespestris Monniera H.B.K.)}

Wet ground. Along the shore and in the shallow water of Barton Creek, Shoal Creek, etc. A prostrate creeping plant with succulent glossy leaves and white flowers.

Southeastern states and in the tropics.

Penstemon Cobaea Nutt. Beard-tongue.

Abundant in dry ground, along railroad tracks and in open woods. One of our most striking and beautiful wild flowers. A coarse plant with smooth leaves and spikes of large bell-shaped cream-colored blossoms. Easily recognized by the yellow-bearded sterile stamen which gives it its popular name.

Texas.

Penstemon Mackayanus K. \& W. Beard-tongue.

In open woods. About half the size of $P$. cobaea. Not common. Texas.

\section{Verbascum Thapsus L. Mullein.}

Flood plains. A large coarse weed with a rosette of large, strikingly fuzzy leaves close to the ground. The spike of yellow flowers is borne on a stout stalk several feet high.

Native of Europe, but very common weed in eastern North America.

Veronica peregrina L. Speedwell. Purslane Speedwell. Muddy ground along streams. River bank, etc.

\section{ACANTHACEAE Acanthus Family}

Calophanes linearis Gray.

Dry ground, roadsides, etc.

Texas, New Mexico and Mexico.

Dianthera americana L. Water Willow.

A very common weed rooting in the mud and growing half submerged in small streams. Abundant in Shoal Creek, and Barton Creek.

Widespread in the eastern half of the continent. 
Diapedium brachiatum Kuntze. (Dicliptera brachiata Spreng.)

Moist woods.

Southeastern states.

Ruellia Drummondiana A. Gray.

Dry ground. Less common than the following species and with smaller flowers.

Texas.

Ruellia tuberosa L. Wild Petunia.

Very common in dry ground. Blooming in the summer and fall. Abundant on the University campus. With large, purple-blue flowers.

Texas and tropical America.

Siphonorlossa Pilosella Torr.

Texas to Mexico.

\section{PINGUICULACEAE (LENTIBULARIACEAE) Bladderwort Family}

Utricularia subulata L. Bladderwort.

A very delicate almost thread-like plant rooting in the mud and floating in the water at Barton Spring. Rare.

Atlantic and Gulf states and tropical America.

\section{BIGNONIACEAE Trumpet-creeper Family}

Campsis radicans Seem. (Tecoma radicans DC.) Trumpet Creeper. Moist woods of flood plains. Not abundant here. A climbing vine with large orange-red, trumpet shaped flowers. Often planted in yards. Abundant in moist woods in the southeastern states. Common in east Texas.

MARTYNIACEAE Unicorn-plant Family (Under PEDALIACEAE)

Martynia Louisiana Mill. Unicorn plant. Devil's Claws. Ram's horn.

River flood plain. The pod is several inches long and has a slender, hooked beak.

Eastern United States.

\section{PLANTAGINALES}

\section{PLANTAGINACEAE Plantain Family}

Plantago aristata Michx. Plantain.

Dry, onen oround. Not common here, but abundant on uplands in other parts of the state.

Plains and prairie states, and spreading Eastward. 
Plantago heterophylla. Nutt. Plantain.

Low, moist ground. A small plant with linear leaves.

Southeastern states.

Plantago rhodosperma Decn. Plantain.

Our most common species. Abundant on roadsides and in waste places. University campus. A large form with broad, hairy leaves and red seeds.

Southern central states.

Plantago Wrightiana Decn. Plantain.

Abundant on roadsides, hillsides and waste places.

Texas.

\section{SANTALALES}

\section{LORANTHACEAE Mistletoe Family}

Phoradendron flavescens Nutt. Mistletoe.

Abundant on various trees in Austin.

Southeastern states.

\section{RUBIALES}

\section{RUBIACEAE Madder Family}

Cephalanthus occidentalis L. Button-bush.

Common near the mouths of ravines, in moist soil. A shrub with leaves and branches often in threes. The small white flowers in dense spherical heads have given rise to the popular name.

Widespread in North America.

Crusea tricocca Heller. (C. Alococca Gray.)

Dry ground.

Texas and Mexico.

Galium aparine L. Bedstraw.

Common in rich soil in woods and thickets. The weak, slender stems four-angled and armed with recurved prickles. The narrow leaves in whorls of seven.

Widespread in North America.

Galium texanum Wiegand. Bedstraw.

Common in dry woods. Smaller than the preceding, and with leaves in whorls of four.

Texas. 
Galium virgatum Nutt. Bedstraw.

Common in dry woods. Similar to the preceding, the leaves in fours.

Southeastern states.

Houstonia angustifolia Michx.

Abundant in dry, open ground. University campus. With slender, much-branched stems, narrow leaves and small pink flowers.

Southern states.

Houstonia humifusa A. Gray.

A low, densely tufted annual, with pink fliwers similar to $H$. augustifolia. Found occasionally in dry ground. River flood plain.

Texas and eastern New Mexico.

Houstonia subviscosa Gray.

In low ground along the railroad tracks. Rare.

Texas.

\section{CAPRIFOLIACEAE Honeysuckle Family}

Lonicera albiflora T. \& G. Honeysuckle.

Common in woods and thickets.

Southern central states.

Nintooa Japonica Sweet. (Lonicera Japonica Thurb.) Japanese Honeysuckle.

Escaped from gardens and growing wild in waste places. Bank of Waller Creek.

Native of Eastern. Asia. Naturalized in eastern United States.

Symphoricarpos Symphoricarpos L. Coralberry.

Shaded bluffs. Onion Creek.

Sambucus canadensis L. Elder.

Occasional in valleys. Bull Creek, Onion Creek, and the Colorado River flood plain.

Widespread in eastern North America.

Viburnum prunifolium L. Black Haw.

In ravines of the Edwards Plateau. Less common than the following.

Widespread in eastern United States. 
Viburnum mifotomentasum Small. (V. prunifolium var. ferrugineum T. \& G.) Black Haw.

Common in moist ravines of the Edwards Plateau. A shrub or small tree with glossy, oval leaves, white flowers in flat-topped clusters, and black berries. It differs from the preceding in its rusty tomentose petioles.

Southeastern states.

\section{VALERIANALES}

\section{VALERIANACEAE Valerian Family}

Valerianella amarella Krok. Corn Salad. Lamb Lettuce.

A low plant abundant in low ground and moist uplands. Its opposite branches terminate in flat-topped, conspicuously four-sided clusters of white flowers.

Texas.

Valerianella radiata Dupr. Corn Salad. Lamb Lettuce.

Similar to the preceding. Low ground.

Eastern states.

\section{ARISTOLOCHIALES}

\section{ASARACEAE Birthwort Family}

Aristolochia longifolia Engelm. \& Gray.

Found occasionally in cultivated ground.

Along the Rio Grande.

\section{CAMPANULALES}

\section{CURURBITACEAE Gourd Family}

Cucurbita foetidissima H.B.K. Wild Gourd.

Very common in waste places. A creeping vine with large leaves, ill-scented.

Southern central states to California and Mexico.

Ibervillea Lindheimeri Greene. (Maximowiczia Lindheimeri Cogn.)

Wild Pomegranate, Balsam.

Abundant in thickets on the hills of the Edwards Plateau. A climbing vine with bright red oval fruits.

Southwestern states.

Ibervillea tenella Small. Wild Pomegranate, Balsam.

Ravines and wooded hillsides.

Texas. 
Sicyos angulata L. Star Cucumber. Wild Cucumber. Nimble Kate. Found occasionally in moist gullies. Shoal Creek.

Widespread in eastern North America.

\section{CAMPANULACEAE Bellflower Family}

Specularia biflora Gray. Venus' Looking-glass.

Common in woods and fields. A slender plant with blue, starshaped flowers.

Southern and western states and Mexico.

Specularia coloradoensis Buckl. Venus' Looking-glass.

Rare here.

Texas.

Specularia leptocarpa Gray.

Not abundant here.

Central states.

Specularia perfoliata A. DC. Venus' Looking-glass. Clasping Bell Flower.

Common in woods and valleys. The rounded leaves clasp the stem by their heart-shaped bases.

Widespread in eastern North America.

\section{LOBELIACEAE Lobelia Family}

Lobelia cardinalis L. Cardinal Flower.

Wet soil. Barton Springs. Rare here.

Widespread in eastern North America.

\section{CARDUALES}

AMBROSIACEAE Ragweed Family (Under Tribe Heliantheae of COMPOSITAE)

Ambrosia aptera DC. Giant Ragweed.

Abundant in moist soil on flood plains. Similar to A. trifida of the eastern states.

Te as to Arizona.

Ambrosia psilostachya DC. Western Ragweed. Perennial Ragweed.

Abundant in valleys. Similar to A. artemisaefolia of the eastern states, but perennial.

Central and western states. 
Hymenoclea monogyra T. \& G.

Not common here.

West Texas, Mexico and southern California.

Iva angustifolia Nutt. Marsh Elder.

Banks of Barton Creek.

Southern central states.

Iva ciliata Willd. Marsh Elder. Rough Marsh Elder.

Banks of the river.

Southern central states.

Xanthium speciosum Kearney. Cockle Bur.

Very abundant in flood plains and waste places.

Central states.

\section{CARDUACEAE Thistle Family (Compositae)}

\section{Tribe VERNONIEAE}

Vernonia Baldwinii Torr. Iron weed.

In low open ground. Flood plains. A tall coarse weed with clusters of red-purple flowers.

Scuthern prairie states.

\section{Tribe EUPATORIEAE}

Coleosanthus cylindraceus Kuntze. (Brickellia cylindracea Gray \& Engelm.)

Mt. Bonnell. Onion Creek. In dry ground.

Texas.

Conoclinum coelestinum DC. (Eupatorium coelestinum L.) Blue Boneset. Mist Flower.

Abundant in moist ground in ravines and valleys. Flowers light blue.

Widespread in southeastern and central states.

Eupatorium ageratifolium DC. Thoroughwort.

Common on bluffs and hillsides. Mt. Bonnell. A shrub with triangular opposite leaves and white flowers.

Texas and Mexico.

Eupatorium ageratoides L. F. (Eupatroium urticaefolium Reichard.)

Thoroughwort. White snakeroot.

Common in moist ravines. Similar in appearance to the preceding.

Eastern states and Canada. 
Eupatorium incarnatum Walt. Pink Thoroughwort.

Bull Creek.

Southeastern states to Mexico.

Eupatorium serotinum Michx. Late-flowering Thoroughwort.

Flood plain of Barton Creek.

Southeastern states and central states.

Laciniaria punctata Kuntze. (Liatris punctata Hook.) Blazing Star. Button Snakeroot.

Open dry ground. Along railroad tracks. A perennial plant about two feet high, with stiff linear, finely dotted leaves. The stem is terminated by a dense spike of pink or purple flower heads.

Plains and prairie states to Mexico.

\section{Tribe ASTERIEAE}

Amphyachyris dracunculoides Nutt.

Dry ground.

Southern plains and prairie states.

Aphanostephus humilies A. Gray.

Dry ground.

Texas to Mexico.

Asphanostephus skirrobasis Trelease. (Aphanostephus arkansanus Gray.)

Dry ground.

Southern plains to Mexico.

Aster Drummondii Lindl.

Abundant in woods and thickets. Our most common and most beautiful aster. With large, purple-blue flower heads.

Central states.

Aster dumosus var. subulaefolius Torr. \& Gray.

Abundant along Barton Creek.

Southeastern states.

Aster exilis Ell.

Low ground. Abundant along Barton Creek. A fleshy-stemmed aster with linear leaves.

Southeastern states.

Aster multiflorus Ait. Many-flowered Aster.

Very common in fields and roadsides. The flower heads are small, white and very numerous.

Eastern and central states. 
Aster spinosus Benth. (Leucosyris spinosus Greene.) Spiny Aster.

Abundant in places on the river bank. A partly woody plant with many slender, almost leafless, somewhat spiny, green branches. The leaves fall off early.

From Texas to Mexico and southern California.

Baccharis angustifolia Michx.

A willow-like shrub very abundant in the bed of Barton Creek above the springs.

Southeastern states.

Chaetopappa asteroides DC.

Very common in open places in the postoak woods. A low, slender plant with white, aster-like flowers. An early bloomer.

Missouri to Texas.

Chrysopsis microcephala Small. Golden Aster.

Southeastern states.

Chrysopsis villosa Nutt. Hairy Golden Aster.

Dry cp n ground. University campus.

Plains and prairie States.

Erigeron philadelphicus L. Daisy-fleabane.

Woods and ravines. Heads with very numerous narrow, white rays and yellow disks.

Widespread in North America.

Grindelia sguarrosa Dunal. Gum-plant.

In dry ground along railroad tracks. Not common. A coarse, resinous plant with large heads.

Prairie and plains states.

Gutierrezia texana T. \& G. Broom-weed.

Abundant in open, dry ground, fields and roadsides. A serious pest in pastures. On of our most conspicuous fall weeds. Much branched, with slender branches and small, yellow heads.

Arkansas to Texas. Characteristic of the dry prairies.

Gymnosperma corymbosa DC.

Rocky hill. Mt. Bonnell. Somewhat similar to a golden rod.

$\mathrm{Te}$ as to Arizona and Mexico.

Heterotheca subaxillaries Britt. \& Rusby.

Common in open dry ground. Blooming abundantly in the fall. With rather large, yellow heads.

Southeastern states. 
Keerlia bellidifolia Gray \& Engelm.

Very common on moist, wooded hillsides. A straggling slenderstemmed plant with very small, blue heads.

Texas.

Leptilon canadense Britton. (Erigeron canadensis L.) Horseweed. Canada Fleabane.

Common along roadsides. Much branched, with many very small, white heads.

Widely distributed in North America, South America and Europe.

Solidago canadensis L. Goldenrod.

In ravines, Waller Creek, etc.

Widely distributed in eastern North America.

Solidago nemoralis Ait. Goldenrod.

Dry postoak uplands.

Central and southern states.

Xanthisma texanum DC.

Flood plain of the river. A prairie plant.

Texas.

\section{Tribe INULEAE}

Filago nivea Small. Indian Tobacco.

Common in dry, waste ground. Campus. A small, muchbranched plant with white-woolly leaves and white-woolly heads of very small flowers. The flowers are so buried in the wool as to be almost indistinguishable.

Gulf states to California.

Filago prolifera Britton. (Evax prolifera Nutt.) Indian Tobacco. Similar to the preceding and in similar situations.

Central states.

Gnaphalium purpureum L. Cudweed. Everlasting.

Erect, white-woolly herbs several inches to more than a foot high. Widely distributed in the south from the Atlantic to the Pacific.

Pluchea purpurascens DC. Marsh Fleabane.

Flood plain of Barton Creek.

Gulf states and tropical America. 


\section{Tribe HELIANTHEAE}

Berlandiera texana DC.

Rather tall, white-hairy, weeds with perennial roots and large, conspicuous yellow heads, of which the rays only bear seeds.

Missouri, Louisiana and Texas.

Coreopsis cardaminefolia T. \& G. Tickseed.

Open ground.

Southern prairie states.

Dracopis amplexicaulis Vahl. (Rudbeckia amplexicaulis Cass.)

Shoal Creek Valley.

Gulf states.

Eclipta alba Hassk.

Moist ground. Common on the banks of Shoal Creek and in similar situations.

Eastern and southern states and tropical America.

Encelia calva Gray.

Texas and Mexico.

Engelmannia pinnatifida T. \& G.

Common in ravines and rich soil. A coarse plant, with large, deeply pinnatifid leaves and large, yellow heads.

Southern-central states.

Helianthus annuus L. Sunflower.

Roadsides in low places. The common sunflower.

Central states to California. Commonly cultivated.

Helianthus cinereus T. \& G. Sunflower.

Found near the river. A small sunflower. Not common here.

Texas.

Helianthus Maximiliunii Schrad. Maximilian's Sunflower.

Bull Creek region. A tall plant with large, handsome heads. Planted on the campus near the library.

Central plains and prairies.

Helianthus praccox Engelm.

Very common in roadsides in dry, open places. With triangular leaves, white on the lower surface.

Gulf states. 
Lindheimera texana Gray \& Engelm. Te as Star.

Abundant in open places everywhere. A coarse plant with large, four or five-rayed, yellow heads.

Texas.

Marshallia caespitosa Nutt.

Moist soil in the Edwards Plateau.

Southern prairie states.

Marshallia obovata Beadle \& Boynton.

Moist soil in the Edwards Plateau.

Southeastern states.

Melampodium cinereum DC. Mountain Daisy.

One of the most abundant herbaceous plants of the dry upper slopes of the Edwards Plateau. A perennial with handsome brightwhite heads.

Southern central states.

\section{Parthenium Hysterophorus L.}

Very common on roadsides and waste places. A homely weed with very small dense white heads. When not in bloom the plant rescmbles the western Ragweed.

Gulf states and tropical America.

Rativia columnaries D. Don. Cone Flower. Mexican Hat.

Very common in fields, roadsides and waste ground. Heads with a cylindrical center, and yellow, brownish, red, or parti-colored rays, Ratibida is commonly called Nigger Head, but the elongated center makes this name inappropiate.

Texas. Prairies from Canada to Mexico.

Rudbeckia bicolar Nutt. Nigger Head. Black-eyed Susan. Cone Flower.

Open moist woods. A plant about two feet high; with large heads, dark centers and yellow rays.

Southern central states.

Sanvitalia ocymoides DC.

Abundant on the flood plain of Shoal Creek near the Spring.

Texas and Mexico.

Sclerocarpus uniserialis B. \& H.

Not abundant here.

Texas and Mexico. 
Silphium albiflorum Gray. Rosinweed.

Dry hillsides of the Edwards Plateau.

Texas.

Silphin asperrimum Hook. Rosin-weed.

Dry ground. Rare.

Southern plains and prairies.

Tetragonotheca Texana Gray \& Engelm.

Very common in fields, roadsides and open woods. Easily recognized by its square involucre of four large outer bracts.

Texas and Mexico.

Thelesperma subsimplicifolium. A. Gray.

Common in dry ground. Similar to Coreopsis.

Rays yellow.

Arizona to Texas and Mexico.

Thelesperma trifidum Britton. (T. filifolium Gray.)

Abundant in open, dry ground. Similar to the preceding.

Arkansas and Texas.

Verbesina virginica L. Crownbeard. Frostweed. Ice Plant.

Common in low, open ground, roadsides and waste places. A coarse, rough-leaved plant, sometimes six feet tall, with white flower clusters. It is easily recognized by its large leaves and winged stems.

Southeastern states.

Viguiera helianthoides H.B.K.

Valleys, hillsides, open ground or open woods.

Texas to Arizona and in Mexico.

Ximenesia encelioides Cav. (Verbesina encelioides Benth. \& Hook.)

Waste places. Abundant on roadsides on the river flood plain. Very similar to Helianthus praecox, but with winged fruits.

Southern plains states to Florida.

Zexmenia hispida Gray.

Dry hillsides. Mt. Bonnell.

Texas and Mexico.

\section{Tribe HELENIEAE}

Amblyolepis setigera DC.

River flood plain and on uplands.

Texas prairies. 
Gaillardia pulchella Foug. Indian Blanket. Indian Sunburst.

In fields and roadsides everywhere. One of our most abundant late-spring flowers. The red and orange-rayed heads are familiar to everyone.

Southern plains and prairie states.

Gaillardia suavis Britton \& Rusby.

Abundant in fields and hillsides. Larger than the preceding, but less conspicuous because the heads are usually without rays.

Texas prairies.

Helenium microcephalum DC. Sneezeweed.

Common in valleys. The small heads have yellow rays and a yellow or brown disk. The stems are winged.

Texas.

Helenium tenuifolium Nutt. Sneezeweed. Bitterweed.

Abundant in dry soil and waste places. A low plant with small yelıcw head and many linear leaves. Easily recognized by its strong odor.

Southeastern states.

Hymenopappus artemisaefolius DC.

Texas plains and prairies. Bull Creek region. Rare here.

Texas prairies.

Hymenopappus carolinense Porter.

Abundant in fields, roadsides, and waste places. Campus. A coarse plant with slightly wooly leaves and rayless heads of white flowers.

Southeastern states.

Hymenopappus corymbosus T. \& G.

Fields, roadsides, and waste places.

Southern prairie states.

Pectis angustifolia Torr. Limoncillo.

Rare here.

Southern mountains and plains.

Polypteris callosa Gray.

Abundant on roadsides and open woods of the uplands, particularly in the postoak woods. A stiff, much-branched plant with slender stems, small, narrow leaves, and purple-pink, aster-like heads. Blooming in the fall.

Missouri to Texas. 
Tetraneuris linearifolia Green. (Actinella linearifolia Torr. \& Gray.) Similar to $T$. linearis, but annual. Less abundant.

Southern central states.

Tetraneuris linearis Green. (Actinella scaposa var. linearis Nutt.)

Abundant in dry, open places and stony hillsides. Campus. A rosette of narrow, basal leaves and conspicuous yellow heads borne on a long, slender, leafless stem.

Texas and New Mexico.

Thymophylla pentachäeta Small. (Hymenantherum pentachaetum DC.)

Hills of the Edwards Plateau. Not common here.

Southern plains states and Mexico.

\section{Tribe ANTHEMIDEAE}

Anthemis Cotula L. Mayweed. Dog's Camomile. Dog Fennel. Along the railroad track.

Widespread in North America. Introduced from Europe.

Achillea millefolium L. Yarrow.

Dry, open places. Common. A strong-scented weed with very finely divided leaves and dense, flat-topped clusters of white heads.

Introduced from Europe and Asia and widespread in North America. Very common in the eastern states.

Artemisia mexicana Willd.

Open, dry ground. Not very common here.

Southern plains states and Mexico.

\section{Tribe SENECIONEAE}

Mesadenia tuberosa Britton. (Cacalia tuberosa Nutt.) Indian Plantain.

Flood plain of Bull Creek.

Prairie states.

Senecio ampullaceus Hook. Squaw-weed.

Abundant in the river flood plain. A tall, coarse weed with large, white-wooly leaves and yellow heads.

Texas.

Senecio lobatus Pers.

Valleys and flood plains.

Southeastern states to Mexico. 
Senecio obovatus Muhl.

Valleys and flood plains.

Eastern states and Canada.

\section{Tribe CYNAREAE}

Carduus austrinus Small. Thistle.

Abundant in low ground, fields and roadsides. The common thistle.

Texas.

Centaurea americana Nutt. Star Thistle.

Roadsides in low ground.

A tall thistle with pink or whitish heads three or four inches in diameter.

Southern plains and prairies to Mexico.

\section{Tribe MUTISIEAE}

Thyrsanthema nutans Kuntze. (Chaptalia nutans Hemsl.)

Rich, moist soil on bluffs and in ravines of the Edwards Plateau. A rosette cf woolly leaves at the ground and a leafless stem bearing a nodding head of pink flowers.

Texas and Mexico.

\section{CICHOREACEAE Chicory Family}

(Tribe Cichoreaceae under Compositae.)

Adopogon occidentalis Kuntze. (Krigia occidentalis Nutt.) Dwarf Dandelion.

Abundant in level uplands of the post-oak region. In woods and pastures.

Southern prairie states.

Lactuca ludoviciana DC. Wild Lettuce.

Roadsides and waste places.

Prairie states.

Lactuca virosa L. (L. scariola L.) Prickly Lettuce. Compass Plant. Roadsides and waste places. The leaves by the twisting of their bases tend to stand vertically pointing north and south.

Introduced from Europe and widespread in North America.

Lygodesmia texana Green. (L. aphylla var. texana T. \& G.)

Dry ground. Roadsides. University campus. An almost leafless plant with slender, green branches and large, delicate, lavender heads.

Texas. 
Pinaropappus roseus Lens.

Common in ravines and bluffs of the Edwards Plateau.

Texas and Mexico.

Serinea oppositifolia Kuntze. (Apogon humilis Ell.)

Shoal Creek Valley.

Southeastern states.

Sitilias grandiflora Greene. False Dandelion.

River flood plain.

Southern prairie states.

Sitilas multicaulis Green. (Pyrrhopappus multicaulis DC.) False Dandelion. Dandelion.

Very common in open ground. Campus.

Gulf states to Arizona and Mexico.

Sonchus asper All. Sow Thistle.

Roadsides and waste ground. One of our most common weeds. A coarse plant with prickly-margined leaves and small yellow heads. Widespread in North America.

Sonchus oleraceus L. Sow Thistle.

Similar to the other and in similar locations; equally abundant. Widespread in North America. Naturalized from Europe.

Taraxacum Taraxacum Karst. Dandelion. (T. officinale Weber.)

Occasional in roadsides here. Coming in from the Northeastern States.

A cosmopolitan weed. 



\section{N D E X}

Abutilon holosericeum Scheele..... Abutilon incanum Sweet........... Abutilon texense T. and G.......... Abutilon wrightii A. Gray.......... Acacia filicoides Trelease........... Acacia Roemerianna Schlect......... Acalypha gracilens var. monococcus

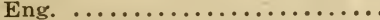
Acalypha Lindheimeri Muell. Arg... Acalypha ostryaefolia Rydb. ........ Acalypha radians Torr.............

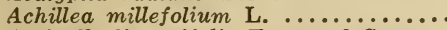
Actinella linearifolia Torr and Gray.. Actinella scaposa var. linearis Nutt.. Acuan Illinoensis Kuntze...........

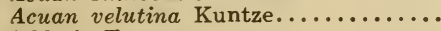

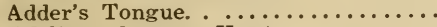
Adelia pubescens Kuntze........... Adiantum Capillus-veneris L. .....

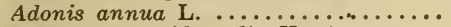
Adopogon occidentalis Kuntze....... Aesculus Pavia L. ................

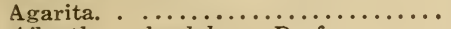
Ailanthus glandulosus Desf. ........ Alfalfa. . . . . . . . . . . . . . Alfilaria..$\ldots \ldots \ldots \ldots \ldots \ldots \ldots$ Allionia albida Walt. .............. Allionia nyctaginea Michx. .........

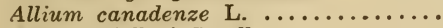

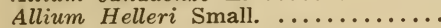
Allium microscordion Small. ........

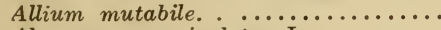
Alopecurus geniculatus L. .......... Aloysia ligustrima Small. ......... Alsine Baldwinii Small. ............

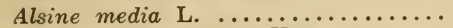
Alternanthera repens Kuntze........

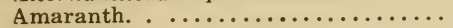

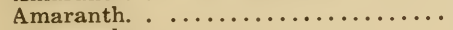

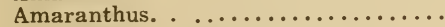

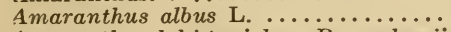
4 maranthus b $l i t o i d e s$ Reverchonii

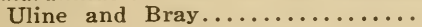
Amaranthus Palmeri S. Wats. ...... Amaranthus Pringlei Watson......... A maranthus retroflexus L. .........

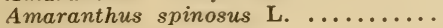
Amaryllis.

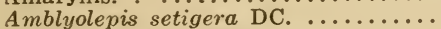
Ambrosia aptera DC.

Ambrosia psilostachya DC. ......... Ammannia coccinea Rottb. .........

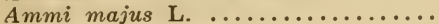

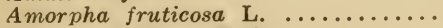
Amorpha texana Buckl. ........... Ammoselinum Butleri Coult. \& Rose Ampelopsis arborea Rusby........... Amphilophis saccharoides (Sw.) Nash. Amphyachyris dracunculoides Nutt. . Amsonia texana Heller.............

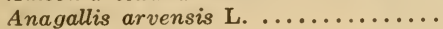

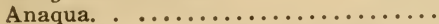
Andropogon argyraceus Schult. .... Andropogon glomeratus B. S. P.... Androstephium coeruleum Greene....

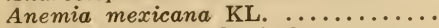
Anemone decapetala Ard. ..........

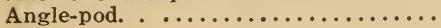

Annual Poa. ................. 14

Antelope Horns. . .............. 61

Anthemis Cotula L. ............. 85

Antirrhinum antirrhiniflorum Small. 70

Aphanostephus humilis A. Gray.... 78

Aphanostephus arkansanus. . ..... 78

Aphanostephus skirrobasis Trelease... 78

A pium ammi Urban. . ......... 56

A pogon humilis Ell. ............... 87

Aquilegia canadensis L. .......... 29

Aquilegia chrysantha Gray......... 29

Arabis petiolaris A. Gray.......... 31

Arabis virginica Trelease......... 31

Arbutus Xalapensis H.B.K. ....... 58

Arenaria Benthamii Fenzl. ........ 28

Argemone alba Lesteb. ........... 31 Argemone Platyceras Link \& Otto.. 31 Argythamnia humilis Muelk. ...... 45 Argythamnia mercurialina Nutt.... 45

Arisaema dracontium Schott. ...... 16

Aristida longiseta Steud. .......... 11

Aristida purpurea Nutt. .......... 11

Aristolochia longifolia Engelm. and Gray........................ 75

Arrow-leaf, Arrow-head. . ........ 8

Artemisia mexicana Willd. ........ 85

Asclepias Lindheimeri Engelm. .... 60

Asclepias texana Heller............ 61

Asclepias verticillata L. ......... 61

Asclepiodora decumbens A. Gray.... 61

Asclepiodora viridis A. Gray....... 61

Ascyrum hypericoides L. ........ 51

Ash-leaved Maple. . ............ 48

Asplenium resiliens Kuntze........ 5

Aster Drummondii Lindl. ......... 78

Aster dumosus var. subulaefolius

Torr. and Gray................ 78

Aster exilis Ell.................. 78

Aster multiflorus Ait. .......... 78

Aster spinosus Benth. ............ 79

Astragalus crassicarpus Nutt. .... 37

Astragalus leptocarpus T. and G.... 38

Astragalus Lindheimeri Engelm.... 38

Astragalus Mexicanus A. D.C..... 38

Astragalus Nuttalianus DC. ....... 38

Astragalus reflexus $\mathrm{T}$. and $\mathrm{G} . \ldots . .37$

Astragalus Wrightii AG. ........ 37

Atamosco Lily. . .............. 19

Atamosco texana Green.................. 19

Atheropogon curtipendulus Tourn... 12

Avens. ......................... 34

Baccharis angustifolia Michx. ..... 79

Ball Moss. . ................. 17

Balloon Vine. ................ 48

Ba!sam. . ..................... 75

Bear-berry. . ............... 47

Beard-tongue. . .............. 71

Bedstraw. . .................. T3

Bee Blossom. . ............... 54

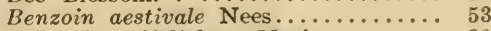

Berberis trifoliolata Moric......... 30

Berchemia scandens Trelease........ 48

Berlandiera texana DC. ............ 81

Bernardia myricaefolia S. Wats.... 44

Berula erecta (Huds). Coville..... 56

Bindweed. . ................. 62 
Bird Pepper

Bitterweed.

Black Bind

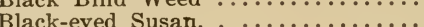

Black Haw.

Black Haw.

Black Snake-root ................

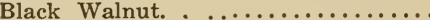

Black Willow. . ..................

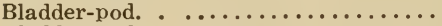

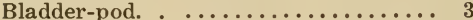

Bladderwort. . ........................ 72

Blazing Star ............... 78

Blue Bonnet, Lupine ........... 38

Blue Gentian. . ............... 60

Blue Larkspur. . .............. 30

Blue Sage. ................ 69

Blue Violet. ................. 52

Boerhaavia decumbens Vahl. ..... 27

Boerhaavia erecta L. ............ 27

Boehmeria cylindrica Willd. ...... 22

Bois D'Arc ................... 23

Bosc's Goosefoot. . ............. 25

Bouteloua curtipendula Torr. ...... 12

Bouteloua hirsuta Lag. ............ 12

Bouteloua texana S. Wats. ......... 13

Boutelou trifida Thurb. .......... 12

Bowlesia septentrionalis Coult. and

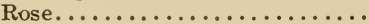

Bouchetia anomala Brit. and Rusby. 64

Bow wood. . .................. 23

Box Elder. .................. 48

Brassica Juncea Cosson ........... 31

Brayondendron texanus Small..... 58

Brayulinea densa Small........... 26

Brazoria scutellarioides Engelm. and

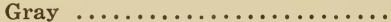

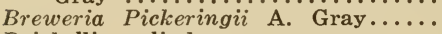

Brickellia cylindracea. . ............

Bromus purgans texensis Shear. ... 13

Bromus secalinus L. ............ 13

Bromus unioloides H.B.K. ......... 13

Broom-weed. . .................... 79

Broussonetia papyrifera Vent..... 23

Buckthorn. . ................ 48

Buddleia ramosa Torr. ........... 59

Buffalo Bur ................. 65

Bulbilis dactyloides Raf. .......... 12

Bull Nettle. . .................. 44

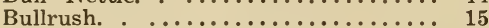

Bumelia lanuginosa Pers. ......... 58

Bur Clover. . ................. 39

Bur Clover, Spotted Medic......... 39

Bur-grass. . ................ 9

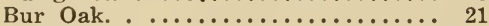

Bur Nut. . ...................... 42

Bursa Bursa-pastoris Brit. ......... 31

Bush Clover. ............... 38

Bushy Knotweed. . ............... 24

Buttercup. ................. 54

Buttercup, Crowfoot. . ......... 30

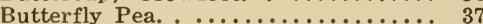

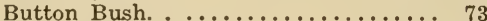

Button Snake Root.................. 57

Cacalia tuberosa Nutt. ........... 85

Cactus missouriensis Kuntze ....... 52

Calceoloria verticillata Kuntze ...... 52

Callicarpa americana L. .......... 66

Callirrhoe digitata Nutt. ......... 50

Callirrhoe papaver A. Gray........ 50

Callitriche heterophylla Pursh. ..... 47

Calophanes linearis Gray......... 71

Caltrop. ........................ 42

Camassia Fraseri Torr. .......... 18
Campsis radicans Seem. ......... 72

Capnoides curvisiliquum Kuntze.... 31

Capriola dactylon Kuntze........... 12

Capsella bursa-pastoris Moench. .... 31

Capsicum baccatum L. ............ 64

Cardinal Flower .................. 76

Cardiospermum Halicacabum L. ... 48

Carduus austrinus Small. Thistle.... 86

Carex amphibola Steud. ........... 15

Carex cherokeensis Schwein. ...... 15

Sarex triangularis Boeckl. ......... 15

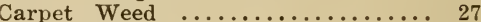

Carpet Weed ................... 44

Cassia Lindheimerianna Scheele. ... 36

Cassia occidentalis L. ............. 36

Cassia Roemeriana Scheele ........ 36

Castilleja Lindheimeri Gray ........ 70

Castor Bean. ................. 46

Sat-briar. ................. 19

Jat Claw .................... 35

Cathartolinum multicaule Hook..... 41

Sathartolinum rigidum Pursh. ...... 41

Jathartolinum rupestre Englem. ... 41

at-tail. . ................... 8

Jeanothus ovatus Desf. .............. 48

Tebatha caroliniana Britton........ 30

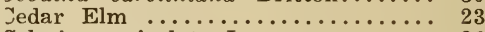

Jelosia paniculata L. .............. 26

Teltis mississippiensis Bosc. ......... 23

Jeltis reticulata Torr. ............ 23

Genchrus tribuloides L. ........... 9

Jentaurea americana Nutt. .......... 86

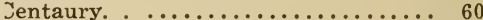

Jephalanthus occidentalis $\mathrm{L}$. ........ 73

Terastium brachypodium Robinson.. 28

Jerastium longipedunculatum Muh... 28

Cerastium viscosum L. . ........... 28

Seratophyllum demersum L. ........ 29

Sercis occidentalis Torr. ........... 36

Shaerophyllum Teinturieri Hook.... 56

Chaetochloa composita Scribn. ..... 10

Chactochloa glauca Scribn. ............ 10

Shaetochloa verticillata Scribn........ 10

Chaetopappa asteroides DC. ......... 79

Chamaesaracha conioides Britton.... 64

Chamaesaracha Coronopus A. Gray.. 64

Chamaesyce Fendleri Small ....... 44

Shamaesyce maculata Small........ 44

Chamaesyce nutans Small .......... 44

Shamaesyce Nuttallii Small........ 44

Shamaesyce prostrata Small ........ 44

Chamaesyce serpens Small .......... 44

Chamaesyce villifera Small.......... 44

Chaparral .................. 30

"Chaparral Millett"................... 10

Chaptalia nutans Hemsl. ........... 86

Cheilanthes alabamensis Kuntze... 5

Chenopedium album L. ............ 25

Chenopodium anthelminticum L.... 25

Chenopodium Boscianum Moq. ...... 25

Chenopodium Fremontii S. Wats. ... 25

Chervil. ................. 56

Chess, cheat. . ..................... 13

Chickasaw Plum. . ............. 35

Chicken Grape. . ............... 50

Chickweed. ....................... 28

Chiltipin. . ................ 64

Chinaberry. $\ldots \ldots \ldots \ldots \ldots \ldots \ldots \ldots \ldots \ldots \ldots$. 43

China Tree. ............... 43

Chloris cucullata Bisch. ........... 12

Chloris tenuispica Nash.................... 12

Chloris verticillata Nutt. .............. 12

Chrysopsis microcephala Small...... 79

Chrysopsis villosa Nutt. .......... 79

Cissus incisa Desmoul............. 49 
Clammy Weed.

Clasping Bell

Claytoni

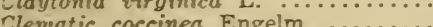

Clemat is Drummondii T. \& G. ..... 2

Sliff-brake.

Climbing Milkweed.

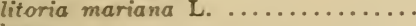

C'over. . .................. 40

Cnidoscolus stimulosus A. Gray.... 44

Coccr's carolinus D.C. .......... 30

Cockle Bur. . ................. it

Coleosanthus cylindricus Kuntze....

Coleostylis Lindheimeri Small ..... 59

Colubrina texensis A. Gras........... 49

Commelina angustifolia Mich(?).... 16

Commelina crispa Wooton.......... 16

Commelina erecta L. ............. 16

Commelina virginica L. ......... 16

Common Peppergrass .......... 32

Compass Plant ................ \&6

Condalia oborata Hook ............. 49

Condalia obtusifolia ............. 49

Cone Flower. ............... 8 ?

Conobea multifida Benth. ........ 70

Conoclinum coelestinum DC. ........

Convolvulus hermannioides A. Gray.

Convolvulus incanus Vahl. .........

Cooperia pedunculata Herb. ....... 19

Coral Bead. . ................. 30

Coral Bean. . ................ 40

Coralberry. . ............... 74

Coreopsis cardaminefolia $\mathrm{T}$. and $\mathrm{G}$. 81

Jork Elm. ................ 23

Corn Salad.

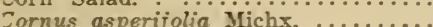

Jorydalis currisiliqua Engelm. ....... 31

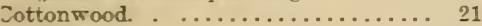

Zrane's Bill. . ................ 41

Irataegus sp. ................. 35

Zreeping Mesquite. . ............. 9

Zreeping Selaginella ..............

Groton fruticulosus Engelm. ........ 45

Groton monanthogimus Michx. .... 45

Groton texensis (Muell.) Arg. ..... 45

Zrownbeard. . ................. 83

Crow-poison. .................... 18

Crusea tricoced Heller ............

Cucurbita foetidissima H.B.K. ....

Cudweed. ................... so

Curl Dock. . ................. 24

Curly-leaved Day-flower. . .......... 16

Cuscuta arvensis Berrich......... 62

Cuscuta Gronorii Willd. ............ 6 ?

Cinoctonum Mitreola Britton.......6.60

Cyperus ferax Vahl. .............. 15

Cyperus filiculmis Vahl. ............ 15

Cyperus rotundus L. ............ 15

Cypress, Swamp Cypress, Bald Cy-

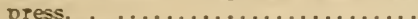

Daisy-fleabane.

Dalea aurea Nutt.

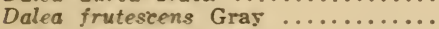

Dalea laxiflora Pursh.

Datura meteloides DC. ........... 64

Datura Stramonium L. ............. 64

Daubentonia longifolia D.C. ........ 37

Daueus Carota L. .................. 56

Daucus pusillus Michx. .......... 5i

Day Flower. .................... 16

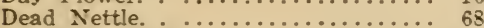

Deciduous Holly. . ............. 47

Delphinium albescens Rydb. ........ 30

Delphinium carolinianum Walt. .... \$0
Dendropogon ssneoides Paf. ....... 17

Desmanthus brachylobus Berth. ..... 35

Desmanthus velutinus Scheele....... 35

Deemodium Wrightii Gray ......... 39

Devil's Claws. . ............... 72

Devil's Pin-cushion ............ 52

Dewberry. . .......................... 34

Dianthera americana $\mathrm{L}$.............

Diapedium brachiatum Kuntze ..... -2

Dichondra carolinense Michx. ........ 61

Dichromena colorata Hitchcock...... 15

Dichromena nirea Boeckl. .......... 15

Dichrophyllum bicolor Kl. \& Garcke.. 45

Dichrophyllum marginatum KI. and Garcke.

Dicliptera brachiata Spreng. .......

Diospyros texana Scheele............ 58

Ditaris humilis $\mathrm{Pax} . . . . . . . . . . . .4 .45$

D:taxis mercurialina Coulter........ 45

Dodder. . ................ 62

Dodecatheon Meadia L. .............. 58

Dog's Camomile. . ............. 85

Dog Fennel. . ................... 85

Dogwood. . ................ 56

Dolicholus terensis Vail........... 37

Downy Grape. . ............... 50

Draba euneifolia Nutt. ............. 32

Draba platycarpa $\mathrm{T}$. and G. ...... 32

Dracopis amplexicaulis Vahl. ..... 81

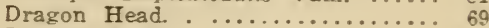

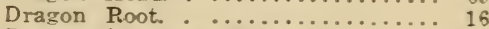

Dryopteris patens Kuntze .......... 5

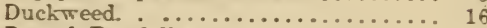

Dwarf Dandelion. . ................. 86

Echinocactus setispinus Engelm... 52

Echinocactur texensis Hoepf. ..... 52

Echinocereus caespitosus Engelm. and Gray.

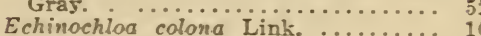

Eclipta alba Hassk. ............. 81

Ehretia elliptica DC. '.............. 66

Elder. . ....

Eleusine indica Gaertn. ............ 13

Elymus canadensis L. ............. 1

Encelia calva Gray ................. 81

Engelmannia pinnatifida T. and G.. \&I

Enslenia albida Nutt. ............6. 61

Ephedra neradensis Wats. ............

Equisetum robustum A. Br........ 6

Eragrostis pilosa Beaur. ............ 13

Eragrostis secundiflora Presl. ....... 13

Eragrostis capillaris Nees. .......... 13

Erigeron canadensis L. ............ 80

Erigeron philadelphicus L......... 79

Eriogonum longifolium Nutt. ..... 23

Erioneuron pilosum Nash........... 13

Erodium cicutarium L'Her. ........ 41

Erodium texanum A. Gray. ........ 41

Eryngium Leatenucorthii T. and G... 5

Erythraea Beyrichii T. and G...... 60

Erythraea calycosa Buckl. ........ 60

Eupatorium ageratifolium DC. ...... -

Eupatorium ageratoides L. F..........

Eupatorium coelestinum L. .........

Eupatorium incarnatum Wait...... Ts

Eupatorium serotinum Michx. ..... is

Eupatroium urticaefolium Reichard.. -

Euphorbia arkansana rar. Missouriensis Norton

Euphorbia bicolor E............... 46

Euphorbia commutata Encelm. ... 46

Euphorbia dentata Michx. ......... 45

Euphorbia dictyosperma $F$. and M. 46

Euphorbia Fendleri T. and G...... 44

Euphorbia heterophylla L. ........ 46 
Euphorbia heterophylla var. grami-

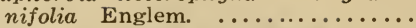
E'uphorbia Longicuris Scheele.......

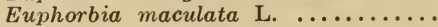
Euphorbia marginata Pursh. ...... Euphorbia petaloidea var. Nuttalli

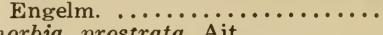

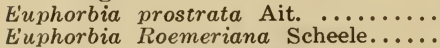

Euphorbia villifera Scheele..........

Eustoma Russellianum Grisib. ......

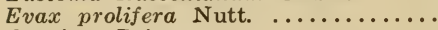

Evening Primrose

Evening Primrose. . ............ 54

Evergreen Sumac ............. 47

Everlasting. . .............. 80

E'volvulus pilosus Nutt............ 62

Evolvulus sericeus Sw. .......... 62

Eysenhardtia amorphoides H.B.K... 37

Fagara Clava-Herculis Small ...... 42

Fagara fruticosa Small.......... 42

False Dandelion. . ............ 87

False Garlic. . ................ 18

False Gromwell. $\ldots \ldots \ldots \ldots \ldots \ldots \ldots 66$

False Indigo. . ............. 37

False Nettle. ................ 23

Festuca octoflora Walt. .......... 13

Filago nivea Small............. 80

Filago prolifera Britton........... 80

Five-leaved Ivy. . ............. 49

Flax. . .................... 41

Florida Moss.. .............. 17

Foresteria pubescens Nutt. ...... 59

Forget-me-not. . ............. 66

Forking Whitlow-wort.. . ....... 26

Four O'clock. . ................... 27

Fraxinus lanceolata Borck. ....... 59

Fraxinus texensis Sarg. ............ 59

Fremont's Goose-foot. . .......... 25

French Mulberry. ............. 66

Froelichia campestris Small. . ..... 26

Frost Grape. . .............. 50

Frost Weed. . ................... 52

Frost Weed.. . ............... 83

Fuirena simplex Vahl. ........... 15

Galium aparine L. ............. 73

Ga'ium texanum Wiegand .......... 73

Galium virgatum Nutt. .......... 74

Gaillardia pulchella Foug. .......... 84

Gailardia suavis Britton and Rusby. 84

Garlic. . .................. 18

Garrya Lindheimeri (Torr.) ....... 56

Gaura brachycarpa Small ......... 53

Gaura Drummondii T. and G....... 54

Gaura parviflora Dougl. .......... 54

Gaura sinuata Nutt. ........... 54

Gaura suffulta Engelm. ........... 54

Geopruminon crassicarpum Rydb. ... 37

Geoprumnon Mexicanum Rydg. .... 38

Gerardia heterophylla Nutt. ....... 70

Gerardia strictiflora Benth........ 70

Geranium texanum Heller. . ....... 41

Geum canadense Gmel. .......... 36

Geum Virginianum L. .............. 34

Giant Ragweed. . ............. 76

Gilia incisa Benth. ............ 63

Gilia rigidula Benth. ............ 63

Gilia rubra Heller. . ........... 63

Gleditsia triacanthos L. ............. 36

Gnaphalium purpureum L. ........ 80

Goldenrod. . ................. 80

Gonobolus biflorus Nutt. ......... 61

Gonobolus laevis Michx. .......... 61

Gonobolus reticulatus Englem...... 61

Gossipianthus lanuginosus Moq. .... 26
Grand-daddy, Graybread ........ 29

GRASSES-

Aretic. . ............... 13

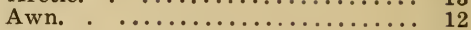

Bear. ....................... 19

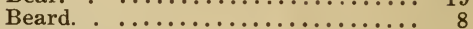

Bermuda. . ............... 12

Black Gramma. . ............ 12

Blue-eyed. . ................ 20

Broad-leaved Spike. . ............ 14

Brome. . .................. 13

Broom. . ................ 9

Buffalo. . ............... 12

Bur. . .................... 9

Canary. . ................ 11

Clustered Love .................. 13

Crab. . . .................11, 13

Fall witch. . ................ 10

Feather. . . . . . . . . . . . . 13

Finger. . ................ 11

Foxtail. . . . . . . . . . . . . 10

Goose. . .................. 13

Hairy Gramma ............... 12

Hairy Spear. . .............. 13

Indian. . . . . . . .

Johnson. $\quad \ldots \ldots \ldots \ldots \ldots \ldots \ldots \ldots \ldots,{ }_{9}$

Lace. . .................... 13

Lyme. . .................... 14

Meadow Foxtail. ............. 11

Mesquite. . ................ 12

Narrow Melic. ............... 14

Needle. . ................. 11

Needle. . .................. 12

Nut. . ................. 15

Pigeon. . . . . . . . . . . . . 10

Porcupine. . .............. 11

Porcupine. . ................ 12

Prickle. . ................. 9

Rescue. . .................. 13

Rice Cut. . .................. 11

Rye. .................. 14

Sheathed. $\ldots \ldots \ldots \ldots \ldots \ldots \ldots \ldots \ldots \ldots \ldots \ldots, 11$

Silver Beard. . ............. 8

Slender Bear. . ................. 18

Slender Rescue. . ............. 13

Slender Meadow. . ............ 13

Southern Canary. . ............. 11

Southern Poverty. . ............ 11

Stagger. . ................ 19

Texas Blue. ............... 14

Texas Gramma. . ........... 13

Tiny Love. ............... 13

Triple Awn. . .................. 11

Water Foxtail. . .............. 11

Water Star. .............. 17

Western Umbrella. . .......... 15

White Prairie. .............. 14

Windmill. . ............... 12

Wire..$\ldots \ldots \ldots \ldots \ldots \ldots \ldots \ldots \ldots \ldots{ }^{10}$

Wire. . .................. 13

Yard. . . . . . . . .

Yellow. $\ldots \ldots \ldots \ldots \ldots \ldots \ldots \ldots \ldots \ldots 10 \ldots \ldots$

Green Ash. . ............... 57

Green-briar. . . . . . . . . . . . 19

Green Dragon. . .................. 16

Green-flowered peppergrass ....... 32

Green Violet. . .............. 52

Grindelia sguarrosı Dunal. ........ 79

Giomwell. . .................. 66

Ground Cherry. . ........... 64

Fround Plum. . .............. 37

Ground Plum. . .................. 38

Guilleminea densa Moq.......... 26 
Gum Elastic.

Gum Plant

Gutierrezia texana $\mathrm{T}$ and $\mathrm{C}$.........

Gymnospermi corymbosa DC. .....

Hackberry.

Hamosa austrina Small ...........

Hamosa leptocarpa Rydb. ..........

Hamosa Lindheimeri Rydh. ........

Hamosa Nuttaliana Rydh. ........

Hartmanniz speciosu Smıll ......

Hawthorne.

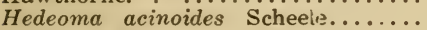

Hedeoma Drummondii Benth. ......

Hedge Nettle.

Hedore Parsley.

Helenium microcephalum DC. ......

Helenium tenuifolium Nutt........

Helianthemum rosmarinifolium Pursh

Helianthus annuus L.

Helianthus cinereus $\mathrm{T}$. and G. .. 81

Helianthus Maximilianii Schrad. ... 81

Helianthus praecox Engelm....... 81

Heliotropium tenellum Torr. ..... 66

Henbit. .................. 68

Herpestris chamaedryoides H.B.K.. 71

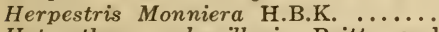

Heterotheca subaxillaris Britt. and

Rusby. . . . . . . . . . . .

Heteranthera dubia McM. ..........

Hicoria Pecan Britton. ..............

var. texana Vasey. . ............

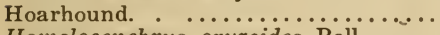

Homolocenchrus oryzoides Poll. ..... 11

Honey Locust. . ................ 36

Honeysuckle. ............... 74

Hop Tree. . ................. 42

Hordeum pusilium Nutt. .......... 14

Horned Pondweed. . ............ 8

Hornwort. . . . . . . . . . . . . .

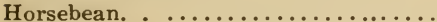

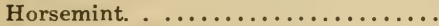

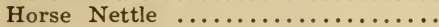

Horsetail, Scouring Rush.........

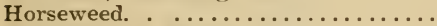

Hosackia Purshiana Benth. ........

Houstonia angustifolia Michx. ......

Houstonia humifusa A. Gray........

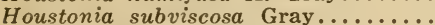

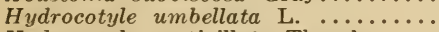

Hydrocotyle verticillata Thumb .....

Hymenantherum pentachaetum. . ...

Hymenoclea monogyra T. and G.....

Hymenopappus artemisaefolius DC...

Hymenopappus carolinense Porter...

Hymenopappus corymbosus T. \& G.

Ibervillea Lindheimeri Greene......

Ibervillea tenella Small............

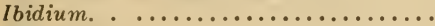

Ice Plant. . .................... 83

llex decidua Watt. ............... 47

Ilex vomitoria Ait. ............. 47

Ill-scented Sumac .............. 47

Indian Blanket. . ............... 84

Indian Cherry ................ 49

Indian Chickweed. . ............. 27

Indian Mallow ................. 50

Indian Mustard. $\ldots \ldots \ldots \ldots \ldots \ldots \ldots . \ldots . \ldots . \ldots . \ldots$

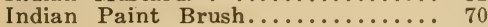

Indian Sunburst ............. 84

Indigo Plant. . ................... 38

Indian Tobacco. ............... 80

Indigofera leptosepala Nutt.......... 38

Ionidium polygalaefolium Vent. ... 52
Ionoxalis Drummondii Rose........ 41

Ipomoea trifida G. Don var. Tor-

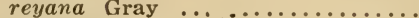

Iron Weed. . ..................... ${ }_{77}$

Isnardia natans Small ........... 54

Iva angustifolia Nutt............ 77

Iva ciliata Willd. ................ 77

Jatropha stimulosa Michx. ....... 44

Jerusalem Cherry. . ............ 64

Jimson Weed. . .............. 64

Joint Fir. . ............... 7

Judas Tree. . .................. 36

Juglans nigra L. ............... 20

Juglans rupestris L. ............. 20

Jujube. ....................... 49

Juncus dichotomus Ell. ................ 17

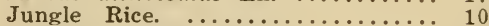

Jussiaea diffusa Forskl. .......... 54

Jussiaea suffruticosa L. ......... 54

Kallstroemia intermedia Vail. ...... 45

Keerlia bellidifolia Gray p Engelm. 80

Krameria secundiflora DC. ....... 36

Krigia occidentalis Nutt. ........ 86

Laciniaria punctata Kuntze ...... 78

Lactuca ludoviciana DC. ........... 86

Lactuca virosa L. ................. 86

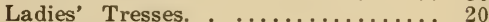

Lamb Lettuce. . ............. 75

Lamb's Quarter. . ................ 25

Lamium amplexicaule L. ........... 68

Lantana horrida H. B. K. ......... 67

Large-flowered Bladder-pod ....... 32

Lathyrus pusillus Ell. ............ 38

Lavauxia triloba Spach. .......... 54

Lavauxia Watsoni Small.......... 54

Lechea tenuifolia Michx. ......... 52

Lemna cyclostasa Chev. ........... 16

Lemna minor L. .................. 16

Leonotis nepetaefolia R. Br. ...... 68

Lepidium apetalum Wild. .......... 32

Lepidium austrinum Small ....... 32

Lepidium medium Greene.......... 32

Lepidium virginicum L. .......... 32

Leptilon canadense Britton.......... 80

Leptochloa mucronata Kunth.......... 13

Lepuropetalon spathulatum Ell. ..... 34

Lespedeza frutescens Brit. ......... 38

Lespedeza procumbens Michx. ..... 38

Lesquerella densiflora S. Wats. ..... 32

Lesquerella Engelmannii S. Wats... 32

Lesquerella gracilis S. Wats. ..... 32

Lesquerella grandiflora S. Wats.... 32

Lesquerella lasiocarpa S. Wats. .... 32

Lesquerella recurvata S. Wats...... 33

Leucophyllum texanum Benth. .... 70

Leucosyris spinosus Greene......... 79

Liatris punctata Hook ........... 79

Limmodea arkansana pilosa Nash.. 9

Limoncillo. . ................ 84

Linaria texana Scheele ............. 70

Lindheimera texana Gray \& Engelm. 82

Lion's Heart. . .............. 69

Lip Fern. . ................ 5

Lippia ligustrina Brit. ........... 66

Lippia nodiflora L. ............ 67

Li'hnopermum breviflorum Engelm. and Gray .................. 65

Lithospernum linearifolium Goldie.. 66

Live Oak. . .................. 23

Lobnlia cardinalis L. ........... 76

Lolium perenne L. .............. 14

Lomatium daucifolium Coult. \& Rose 57

Long Moss. .................. 17

Lonicera albiflora $\mathrm{T}$. and $\mathrm{G}$.......... 74

Lonicera Japonica Thurb. ........ 74 
Loosestrife.

Loti Bush.

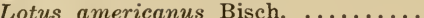

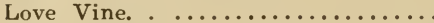

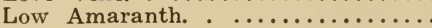

Low Vetchling.

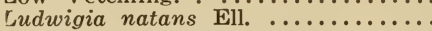

Lupinus texensis Hook .............

Lygodesmia texana Green.........

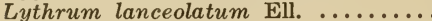

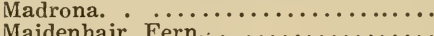

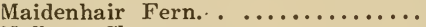

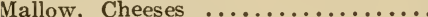

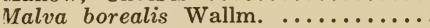

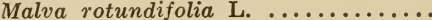

Malvastrum americanum Torr. .... Malvaviscus Drummondii T. and $\mathrm{G}$. Mammillaria missouriensis Sweet...

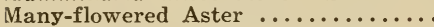
Marilaundium hispidum Kuntze..... Marilaunidium Jamaicense Kuntze.. Marrubium vulgare L. ...........

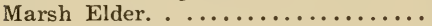

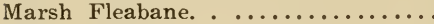

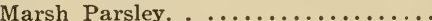

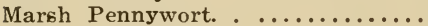
Marsh Purslane.

Marshallia caespitosa Nutt. .......... Marshallia obovata Beadle and Boynton.

Marsilea vestita $\mathrm{Hook}$ and Grev..... Martynia Louisiana Mill. .......... Maximowiczia Lindheimeri Cogn. . Mayweed.

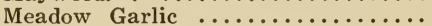
Mecardonia procumbens Small...... Medicago arabica All. ............. Medicago hispida Gaertn. ..........

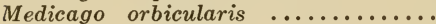

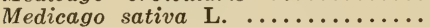
Megapterium Missouriense Spach. .. Meibomia.

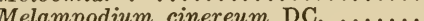

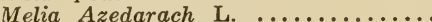

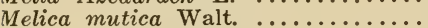

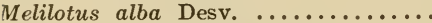

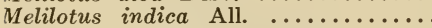
Menodora heteraphylla Moric ......

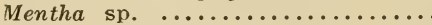

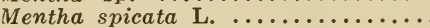
Meriolix melanoglottis Rydb. .......

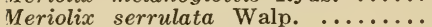
Meriolix spinulosa Heller............ Mesadenia tuberosa Britton.........

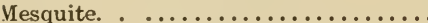
Metastelma barbigerum Scheele....

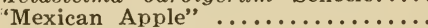

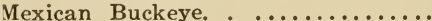
Mexican Hat.

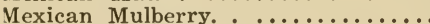

Mexican Persimmon. . ............. Mexican Walnut. Milkweed.

Milkweed.

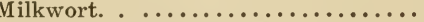

Mimosa fragrans A. Gray......... Mimulus Jamesii Torr. and Gray....

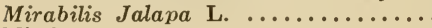
Mistletoe.

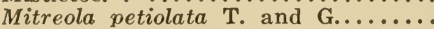
Mitrewort.

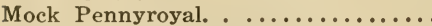

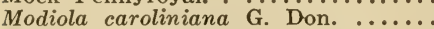

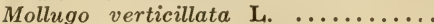
Monarda dispersa Small............
Monarda lasiodonta Small......... 69

Monarda Stanfieldii Small......... 69

Monkey Flower. ............. 71

Monniera Monniera Britton. . .... 71

Monolepsis Nuttaliana Greene...... 25

Morning Glory. ............... 62

Morus microphylla Buckl. ........... 23

Morus rubra L. ................ 23

Morongïa uncinata Britt. ........... 35

Mountain Cedar. ............. 7

Mountain Daisy. . ................... 82

Mountain Laural. . .............. 40

Mountain Live Oak............. 21

Mountain Pink. ..................... 60

Mouse-ear Chickweed. . ........... 28

Mouse-tail. . ................. 30

Muricauda Dracontium Small....... 16

Mustang Grape. . ............ 49

Myosotis virginica $\ddot{B}$. and $\mathrm{P}$....... 66

Myosurus minimus $L$. $\quad$....... 30

Myriophyllum heterophyllum Michx. 55

Myriophyllum roserpinacoides Gil!. 55

Nailwort. . ............... 26

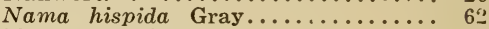

Nama Jamaicense L. .............. 62

Nasturtium officinale $\mathrm{R}$. $\mathrm{Br} . \ldots \ldots . . . .33$

Nazia aliena Scribn. ............ 9

Nemastylis acuta Herb. ............. 19

Nemophila phaceliodies Nutt....... 63

Nettle. . ................. 23

Nicotiana repanda Willd. .......... 64

Nicotiana trigonophylla Dunal .... 64

Niggerhead. . ................ 82

Nightshade. . ............... 65

Nimble Kate. ................ 76

Nintooa Japonica Sweet ......... 74

Nipple Cactus. . .............. 52

Nodding Violet. ................. 52

Nolina Lindheimeriana S. Wats. ... 18

Nolina texana Wats. .................. 18

Notholaena dealbata Kuntze ........ 6

Nothoscordium bivalve Brittch. .... 18

Oenothera Jamesii T. and G...... 55

Oenothera laciniata Hill.......... 55

Oenothera laciniata grandis Britton. 55

Oenothera serrulata T. and G..... 55

Oenothera sinuata L. ............ 55

$O$. sinuata var. grandiflora Heller.. 55

Oenothera triloba Nutt. .......... 54

Oenothera triloba var. parviflora $\mathrm{S}$.

Wats. .................... 54

Onagra jamesii Small.................. 55

Onosmidium Bejariense DC. ....... 66

Onosmodium Helleri Small........... 66

Ophyioglossum Engelmanni Prantle. 5

Opuntia arborescens Eng. ........ 53

Opuntia leptoconlis P. DC. ........ 53

Opuntia Lindheimeri Engelm. ..... 53

Opuntia macrorhiza Engelm. ...... 53

Osage Orange. .............. 23

Oxalis corniculata $\mathrm{L} . \ldots \ldots \ldots \ldots \ldots . . . . . .41$

Oxalis stricta $L$. 42

Oxalis vespertilionis T. and G...... 41

Oxytropis Lambertii Pursh. ....... 39

Padus serotina Agardh. ........... 35

Painted Cup. . ................. 70

Pale Dock. . .................. -

Panicum cognatum Schult. ........ 10

Panicum colonum L. .............. 10

Panicum fuscum Sw. ............... 10

Panicum Helleri Nash................. 10

Panicum Lindheimeri Nash........ 10

Panicum obtusum H.B.K. .......... 10

Panicum Reverchonii Vasey........ 10 


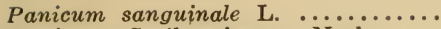
Panicum Scribnerianum Nash......

Panicum texanum Buckl. ..........

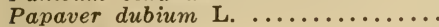

Paper Mulberry.

Parietaria obtusa Rydb.

Parietaria pennsylvanica Muhl. ..... 23

Parkinsonia aculeata L. .......... 36

Paronychia dichotoma Nutt. ........... 26

$P$. Lindheimeri Engelm. ........ 26

Parthenium Hysterophorus L. ..... 82

Parosela aurea Britton. ........... 39

Parosela enneandra Brit. ......... 39

Parosela frutescens Vail.......... 39

Parrots Feather .............. 55

Parthenocissus quinquefolia Planch.. 49

Paspalum Hallii Vasey and Scribn... 11

P. pubiflorum Rupr. ........... 11

Paspalum stramineum Nash....... 11

Pavonia lasiopetala Scheele........ 51

Peach-leaved Dock .............. 24

Pearlwort. . ................ 28

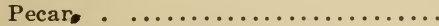

Pectis angustifolia Torr............

Pellaea atropurpurea Link. .........

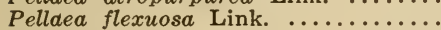

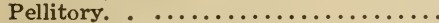

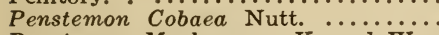

Penstemon Mackayanus $\mathrm{K}$. and W...

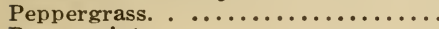

Peppermint.

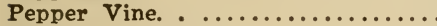

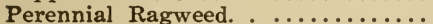

Persicaria hydropiperoides Small....

Persicarla lapathilofia S. F. Gray...

Persicaria pennsylvanica Small.....

Persicaria punctata Small ..........

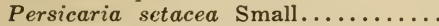

Petalostemon pubescens Heller.......

Petalostemon purpureus Rydb. .....

Petunia parviflora Juss. ............

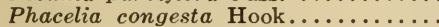

Phacelia patuliflora Gray...........

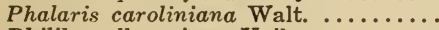

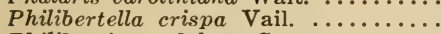

Philibertia undulata Gray...........

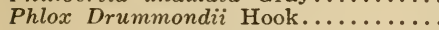

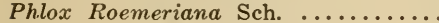

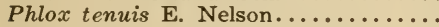

Phoradendron flavescens Nutt. ......

Phyla nodiflora Green.............

Phyllanthus polygonoides Nutt.......

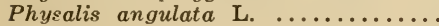

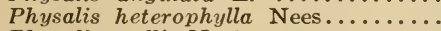

Physalis mollis Nutt. .............

Physostegia intermedia A. Gray.....

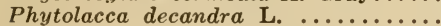

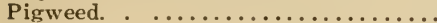

Pigweed.

Pinaropappus roseus Lens. ........

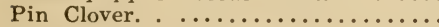

Pinweed.

Plantago aristata Michx. ............

Plantago heterophylla Nutt. ........

Plantago rhodosperma Deen..........

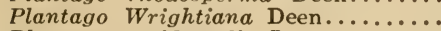

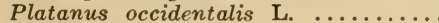

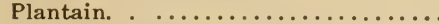

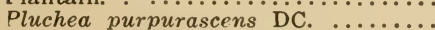

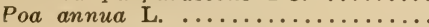

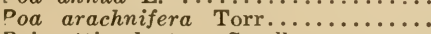

Poinsettia dentata Sma"1...........

Poinsettia havanensis Small.........

Prinsettia heterophylla Small........

Pointed Leaf.
Poison Ivy.

Poison Oak.

$\ldots \ldots \ldots \ldots \ldots \ldots \ldots, 47$

Pokeweed. . ....................... 27

Polanisia graveolens Raf. ......... 33

Polanisia trachysperma T. and G.... 33

Polygala alba Nutt. ............. 43

Polygala Lindheimeri A. Gray..... 43

Polygonum convolvulus L. ......... 24

Polygonum erectum ............. 24

Polygonum hydropiperoides Michx. .. 23

Polygonum lapathifolium L. ....... 24

Polygonum pennsylvanicum L. .... 24

Polygonum punctatum Ell. ......... 24

Polygonum ramosissimum Michx.... 24

Polygonum setaceum Baldw. ........ 24

Polyodon texanus Nash............ 13

Polypodium polypodioides A.S. Hitchcock ( $P$. incanum Sw.) ...........

Polypody. . ................... 6

Polypremum procumbens $\mathrm{L}$......... 60

Polyteris callosa Gray............ 84

Pondweed. . .................... 8

Poppy. . ................... 31

Poppy Mallow. . .............. 50

Populus deltoides Marsh.............. 21

Portulaca lanceolata Engelm. ....... 27

Portulaca oleracea L. .............. 27

Portulaca pilosa L. ............... 28

Possum Haw. . ................ 47

Post Oak. .................. 21

Potamogeton lucens L. ........... 8

Pow der Horn. . . . . . . . . . . . .

Prairie Clover. . ............. 39

Prairie Clover. . ............... 40

Prickly Ash .................. 42

Prickly Lettuce. . ............... 86

Prickly Pear .................... 53

?rickly Solanum ............... 65

Primrose. . .................... 54

Primrose. . ................. 55

Prosopis glandulosa Torr........... 36

Prostrate spurge .............. 44

Prunus americana Marsh............. 35

Drunus angustifolia Marsh........ 35

Prunus serotina Ehrh. ............ 35

Dsoralea cuspidata Pursh............ 40

Psoralea hypogaea Nutt. .......... 40

Psoralea rhombifolia T. and G....... 40

Ptelea trifoliata L. ............. 42

Puccoon. . .................. 66

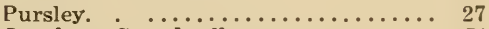

Purslane Speedwell. ........... 71

Pyrrhopappus multicaulis DC. ..... 87

Quamasia hyacinthifolia Britton.... 18

Queen's Delight. . ................ 46

Quercus breviloba Sargent......... 21

Quercus fusiformis Small......... 21

Quercus macrocarpa Michx. ........ 21

2uercus marilandica Muench........ 21

2uercus minor Sargent.............. 21

2uercus schneckii Britton......... 21

2. stellata Wang. .................... 21

2. texana Sarg., not Buckl. ....... 21

Quercus virginiana Mill............. 22

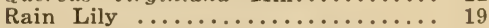

Ranunculus macranthus Scheele.... 30

Ratibida columnaries D. Don........ 82

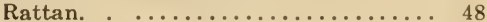

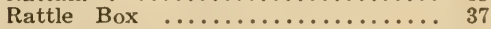

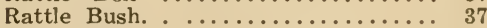

Red Buckeye. . ............... 48

Red-bud. . ................... 36

Red Cedar. . ................ 7

Red Mulberry. . .............. 23 
Red Oak.

Red Plum

Red Root.

(1)

Retama Columbine.............

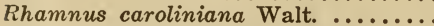

Rhombolytrum albescens Nash....... Rhus canadensis var. trilobata Gray. Rhus copallina var. lanceolata A. Gray.

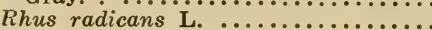

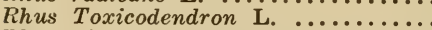

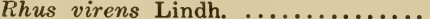
Rhynchosia texana Torr and Gray..

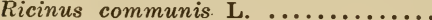

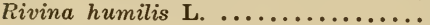
Rock-brush.

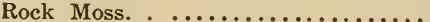

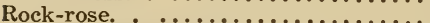

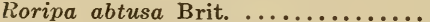

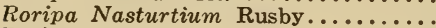
Rosinweed.

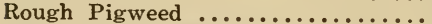

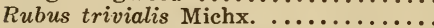
Rudbeckia amplexicaulis Cass....... Rudbeckia bicolor Nutt. ............... Ruellia Drummondiana A. Gray......

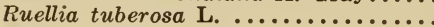

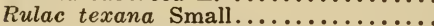

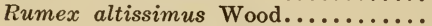
Rumex Berlandıeri Meisn( ?) ........

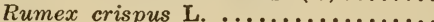

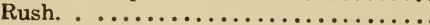
Sabina sabinoides Small (Juniperus sabinoides Sargent ...........

Sabina virginiana Antoine(Juniperus

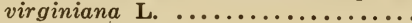
Sagina decumbens T. and G. ........ Sagittaria platyphylla J. G. Smith.. Sabbatia campestris Nutt..........

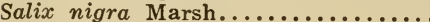

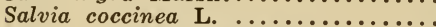

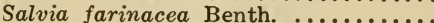
Salvia Roemeriana Scheele.......... Salviastrum texanum Scheele...........

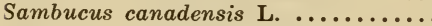

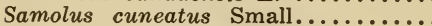

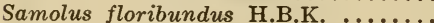

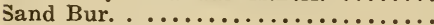

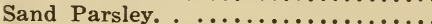

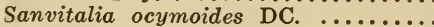
Sandwort.

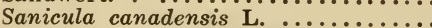

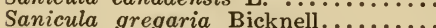
Sapindus Drummondii ............. Schizachyrium scoparium $\mathrm{Nash}(\ddot{A} n$ dropogon scoparius Michx. ...... Schmaltzia lanceolata Small........

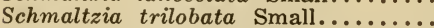
Schmaltzia virens Small................. Schrankia uncinata Willd.

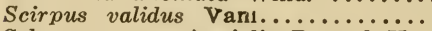
Sclerocarpus uniserialis B. and H... Scutellaria Drummondii Benth......

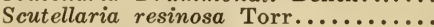
Sedum Nuttalianum Ref. ........... Sedum pulchellum Michx. ............... Sieglingia mutica Kuntze ........... Selaginella apus Spring ............ Selaginella arenicola Underw........ Senecio ampullaceus Hook.............

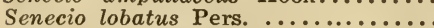

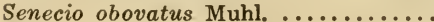
Senna.
21
Sensitive Briar. . ........... 35

Serinea oppositifolia Kuntze......... 87

Sesban macrocarpa Muhl. ......... 40

Sesbania. . ...................... 40

Sesbania Cavanillesii Wats. ......... 37

Setaria glauca L. .................. 10

Setaria verticillata Beauv. ......... 10

Shepherd's Purse .............. 31

Shield Fern. . ...............

Shin Oak ....................... 21

Shittimwood. . .............. 58

Shooting Star. .............. 58

Sicyos angulata $\mathbf{L}$...................

Sida diffusa H.B.K. .............. 51

Sida filipes A. Gray............. 51

Sida filiformis Moris ............. 51

Sida hastata St. Hil............. 51

S. physocalyx A. Gray........... 51

Sida spinosa L. .................. 51

Sieglingia albescens Kuntze........ 14

Silene antirrhina L. ................. 29

Silphium albiflorum Gray ......... 83

Silphium asperrimum Hook......... 83

Siphonoglossa pilosella Torr......... 72

S. brachycarpa Richards.......... 33

Sisymbrium canescens var. brachycarpa Watt. ................. 33

Sisyrinchium minus Engelm. \& Gray 20

Sisyrinchium pruinosum Bicknell... 20

Sitilias grandiflora Greene......... 87

Stilias multicalis Green.............. 87

Skullcap. . ................. 69

Skunk Bush. . .................... 42

Skunk Bush. . ............... 47

Sleepy Catchfly ................ 29

Slender Bladder-pod. . ........... 32

Small-leaved Mulberry ........... 23

Smart Weed. . ................. 24

Smilax Bona-nox L. ................ 19

Snakeroot. . .................... 57

Snapdragon. ................ 70

Sneezeweed. . .................... 84

Snow-on-the-mountain. . ......... 45

Soapberry. . ................. 48

Solanum carolinense L. ................ 65

Solanum eleagnifolium Cav. ......... 65

Solanum heterodoxum Dunal ....... 65

Solanum nigrum L. ............ 65

Solanum rostratum Dunal ............ 65

Solanum Torreyi A. Gray......... 65

Solanum triquetrum Cav........... 65

Solidago canadensis L. .......... 80

Solidago nemoralis Ait. ............ 80

Sonchus asper All. ............... 87

Sonchus oleraceus L. ............ 87

Sophia millefolia Rybd. ............... 33

Sophora affinis T. and G. .......... 40

Sophora secunidflora DC. ........... 40

Sorghastrum nutans Nash........... 9

Sorghum halepense Pers. ......... 9

Sour Grass. . ................... 42

Sour Grass. . .................... 41

Sow Thistle. . .................... 87

Spanish Bayonet ................ 19

Spanish Buckeye ................ 48

Spanish Moss ..................... 17

Spearmint. . ................. 68

Specularia biflora Gray .............. 76

Specularia coloradoensis Buckl. .... 76

Specularia leptocarpa Gray......... 76

Specularia perfoliata A. DC. ........ 76

Speedwell. ..................... 71

Spermolepis echinatus Heller......... 57

Spice Bush. . ............... 53 
Spiderwort.

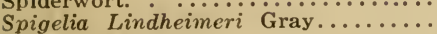

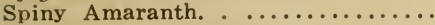

Spiranthes, Gyrostachys ...........

Spleen Wort.

Sporobolus vaginaeflorus Torr......

Spotted Spurge. . ..............

Spring Beauty.

Spurge.

Spurge Nettle.

Squaw-weed.

Stachys agraria $\ldots \ldots . . . . . . . . . .$.

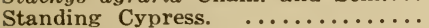

St Andrew's Cross................

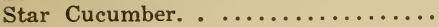

Star Thistle. . ..................

Starwort. . ................ 28

Stellaria media Smith ............... 28

Stellaria prastrata Baldw. ........ 28

Sticktight. . .................. 39

Stillingia linearifolia $\mathrm{Kl}$. and Garcke 46

Stipa leucotricha Trin. .......... 12

Stonecrop. . ................ 34

Stork's Bill. . ............... 41

Stramonium. .............. 64

Streptanthus bracteatus A. Gray.... 33

Streptanthus platycarpus A. Gray.. 33

Stretchberry. . .............. 19

Styrax platanifolia Engelm. ...... 59

Sugarberry. . .............. 66

Sumac. $\ldots \ldots \ldots \ldots \ldots \ldots \ldots \ldots, 47$

Supple-Jack. $\ldots \ldots \ldots \ldots \ldots \ldots \ldots \ldots \ldots . \ldots \ldots 48$

Svida asperifolia Small ......... 56

Swamp Ash ................ 59

Sweet Clover. .............. 39

Sycamore. . ................ 34

Symphoricarpos. . ............. 74

Syntherisma sanguinale Dulac ...... 11

Talinum aurantiacum Engelm. ..... 28

Talinum parviflorum Nutt. ....... 28

Taraxacum Taraxacum Karst. .... 87

Tasajillo. . ................ 53

Taxodium distichum L. C. Rich. ...

Tecoma radicans DC.

Tetragonotheca texana Gray \& Engl.

Tetraneuris linearifolia Green. . ....

Tetraneuris linearis Green..........

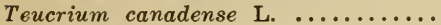

Texas Ash.

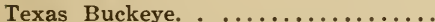

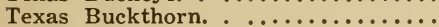

Texas Millet.

Texas Star.

Texas Star.

Thamnosma texana Torr ...........

Thelesperma subsimplicifolium Gray

Thelesperma trifidum Britton.......

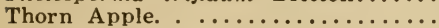

Thoroughwort.

Three-seeded Mercury .............

Thymophylla pentachaeta Small.....

Thyrsanthema nutans Kuntze.......

Tickseed.

Tick Trefoil

Tillaea Drummondii $\mathrm{T}$. and $\mathrm{G} . . . .$.

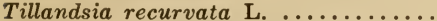

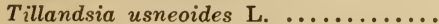

Tilleastrum Drummondii Britton.....

Tiniaria convolvulus Webb and Moq.

Tithymalus arkansanus K1. \& Garcke

Tithymalus commutatus Kl. \& Garcke

Tithymalus longicuris Small.......

Tithymalus missouriensis Small .....

Tithymalus roemerianus Small .....
Toad Flax.

Toothache Tree ............... 42

Toothed Medic. . ............. 39

Toothed Spurge. ............. 45

Torilis nodosa Gaertn. ......... 57

Torrey's Nightshade ............. 65

Toxicoscordion Nuttalii Rydb. .......... 17

Toxylon pomiforum Raf. ......... 23

Tradescantia. ............... 17

Tradescantia gigantia Rose ....... 16

Tradescantia occidentalis Brit. .... 16

Tragia nepetaefolia Cav. ......... 46

Tragia ramosa Torr............. 46

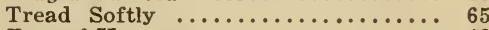

Tree-of-Heaven. . ............. 48

Tribulus terestris i. ............ 42

Tricuspis albescens Munro......... 14

Tridens albescens W. and S. ....... 14

Tridens muticus Nash ............. 14

Trifolium carolinianum Michx. .... 40

Triodia albescens Bent. ........... 14

Trisetum interruptum Buckl. ..... 12

Trumpet Creeper ............. 72

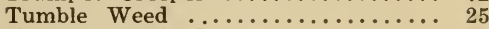

Typha latifolia L. .............. 8

Umbrella-wort. .................. 27

Ulmus alata Michx. ............ 23

Ulmus americana L. ............ 23

Ulmus crassifolia Nutt............ 23

Ungnadia speciosa Endl. ......... 48

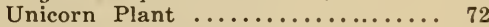

Uniola latifolia Michx. ............ 14

Urtica chamaedryoides Pursh...... 23

Utricularia subulata L. ........... 72

Valerianella amarella Krok. ......... 75

Valerianella radiata Dupr. ........ 75

Venus' Looking-glass ............ 76

Verbascum Thapsus L. Muhein........72

Verbena bipinnatigda Nutt. ....... 67

Verbena canescens H.B.K......... 67

Verbena ciliata Benth............ 67

Verbena officinalis L. ........... 67

Verbena pumila Rydb. ........... 67

Verbesina encelioides Benth. \& Hook 83

Verbesina virginica L. .......... 83

Vernonia Baldwinii Torr.......... 77

Veronica peregrina L. .............. 71

Vervain. .................. 67

Vetch. . ................... 40

Viburnum prunifolium L........... 74

Viburnum rufotomentasum Small.... 75

Vicia Leavenworthii T. and G...... 40

Viguiera helianthoides H.B.K. .... 83

Vincetoxicum biflorum Heller.......6. 61

Vincetoxicum reticulatum Heller..... 61

Viola missouriensis Green......... 52

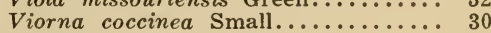

Viorna reticulata Small........... 30

Virgin's Bower. ................ 29

Virginia Rock Cress.............. 31

Vitex Agnus-castus L. ............ 67

Vitis candicans Engelm. ......... 49

Vitis cinerea Engelm. ........... 50

Vilis cordifolia Lam. ............ 50

Virginia Creeper .............. 49

Violet Wood Sorrel.............. 41

Water Cress. . ................ $\mathbf{8 3}$

Water Pimpernel $\ldots \ldots \ldots \ldots \ldots \ldots \ldots \ldots . \ldots \ldots$

Water Milfoil ................. 55

Water Starwort ................. 47

Water Willow ...................... 71

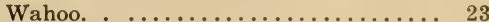

Water Fern ................. 6

Western Ragweed ..................... 76

White-brush. ............... 66 
White Sweet Clover............... 39

White Elm ................... 23

White Larkspur .............. 3

Whitlow Grass ................ 32

White Mulberry $\ldots \ldots \ldots \ldots \ldots \ldots \ldots \ldots, 23$

White Oak .................. 21

Whitetop.

Wild Barley $. . . \ldots \ldots \ldots \ldots \ldots \ldots \ldots \ldots \ldots, 14$

Wild Carrot ............... 56, 5

Wild Cherry .................. 35

Wild China Tree................ 48

Wild Cucumber ................ 76

Wild Geranium $\ldots \ldots \ldots \ldots \ldots$

Wild Gourd $\ldots \ldots \ldots \ldots \ldots \ldots \ldots \ldots .75$

Wild Honeysuckle ............... 54

Wild Hyacinth ................ 18

Wild Lettuce ................. 86

Wild Oats .................... 14

Wild Onion .................. 18

Wild Petunia ................. 72

Wild Rye..$\ldots \ldots \ldots \ldots \ldots \ldots \ldots \ldots \ldots \ldots \ldots$. 14

Wild Water-pepper ............. 23

Wild Yellow Plum ............ 35

Wild Pomegranate $. . \ldots \ldots \ldots \ldots \ldots . .75$

Wild Poppy .................. 31

Wild Tobacco $\ldots \ldots \ldots \ldots \ldots \ldots \ldots \ldots, 64$

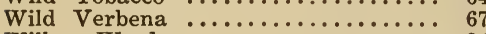

Willow Weed ................. 24
Wine Cup .............. 50

Winged Elm $\ldots \ldots \ldots \ldots \ldots \ldots \ldots \ldots \ldots, 23$

Wissadula holosericea Garcke ...... 51

Woodbine.

Wood Sorrel $\ldots \ldots \ldots \ldots \ldots \ldots \ldots \ldots \ldots \ldots, 42$

Wormseed. $\quad . \ldots \ldots \ldots \ldots \ldots \ldots \ldots \ldots, 25$

Woundwort. .............. 70

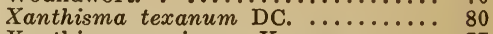

Xanthium speciosum Kearney ...... 77

Xanthoxalis (Oxalis Wrightii Gray) 42

Xanthoxalis corniculata Small...... 41

Xanthoxalis stricta Small ........... 42

Xanthoxylum carolinianum var. fruticosum A. Gray ............ 42 Xanthoxylum Clava-Herculis L.......... 42 Ximenesia encelioides Cav. ........ 83

Yarrow. . ................... 85

Yaupon. . . . . . . . . . . . . 47

Yellow Wild Columbine........... 29

Yellow Wood Sorrel............41, 42

Yucca Arkansana Trelease......... 19

Yucca rupicola Scheele............ 19

Zanichellia palustris L. .......... 8

Zephyranthes texana Herb. ......... 19

Zexmenia hispida Gray............ 83

Ziziphus obtusifolia A. Gray....... 49

Ziziphus vulgaris Lam. ........... 49

Zygadenus Nuttalii S. Wats. ....... 17 